\title{
Rights, Legitimate Expectations, Needs and Responsibilities: \\ UNHCR and the New World Order
}

\section{GEOFF GILBERT*}

'Other maps are such shapes, with their islands and capes!

But we've got our brave Captain to thank'

(So the crew would protest) 'that he's bought $u$ s the best -

A perfect and absolute blank.'

Lewis Carroll, The Hunting of the Snark, Fit the Second, fourth stanza, at p. 56 in The Annotated Snark (ed. Martin Gardner, 1962).

\begin{abstract}
This paper starts from the premise that despite the enlarged role that UNHCR has taken on, particularly since 1989, it is still governed by its original 1950 mandate to provide international protection to refugees, as defined. This extended work has led it to deal with non-refugees, even those who are not even internally displaced, and to carrying out tasks beyond those originally envisaged. Furthermore, its legal personality in international law has increased with its functions, and it is pointless to suggest that UNHCR should return to its original role. Thus, the aim of the paper is to examine what rights UNHCR already possesses which are pertinent to its new-found tasks and what rights it needs visd-vis various actors. In some cases, it is difficult to conceive of the need in terms of a right, and in those cases the object was to highlight a legitimate expectation. If UNHCR has this expanded role, however, the question arises as to its responsibilities in international law. Responsibility has two facets: responsibility for what and to whom. Both aspects are examined, acknowledging that as things stand UNHCR is not sufficiently accountable. The additional difficulty, though, is that in many situations there is multi-agency activity, making it hard to attribute responsibility to any one actor. The conclusion is that these rights and responsibilities need to be codified in some international convention which it
\end{abstract}

- Professor of Law, Human Rights Centre, University of Essex. The author is grateful for the assistance of Françoise Hampson and Nigel Rodley, colleagues at Essex, of Vera Gowlland-Debbas (HEI, Geneva) and of Jean-François Durieux, Jeff Crisp, Eric E. Morris, Nicholas Morris, Volker Turk, Ann Encontre, Karin Landgren and Rick Towle (UNHCR, Geneva). This paper also benefited from lectures at the Human Rights Centre, University of Essex, by Alex Neve on the Great Lakes Crisis, and by Maric-Claude Roberge (ICRC) on international criminal tribunals. Finally, thanks are also due to all the LL.M. in International Human Rights Law students who have listened to me working out these ideas and challenged me about them, particularly the class of 1996-97..As always, the views expressed and any errors are mine alone.

International Journal of Refugee Law Vol. 10 No. 3

Oxford University Press 1998 
is open to UNHCR, and other IGOs possibly, to join. While mere paper rights are of no direct, practical consequence, the fact that UNHCR workers can at least assert them in their dealings with State officials when they are being denied and that a modern clarification of the mandate will be established, has to be of benefit.

\section{Introduction}

To paraphrase Mark Twain, news of the demise of the Westphalian State, and its concomitant sovereign status, has been much exaggerated. While the certainties of the bipolar world of East-West confrontation have passed, there has been little evidence of States renouncing their sovereignty. Rather, alongside an increased number of States, one now has to cope with interdependent associations of States and simultaneous demands for autonomy by ethnic groups ${ }^{1}$ within States. ${ }^{2}$ Furthermore, armed conflicts are rarely inter-State any more, but are internal, often with more than two parties thereto and with a loose chain of command between what passes for the army's headquarters and those fighting on the ground. Conflicts are fragmented. ${ }^{3}$ And into all this uncertainty, the United Nations and its agencies have, in part, been thrust and have, in part, strode out. The reduction in superpower confrontation within the Security Council has meant that the United Nations has deployed or has authorized the deployment of forces to 'solve' humanitarian crises. ${ }^{4}$ Along with the military forces, the humanitarian agencies have had to cope with a 'new world disorder', where they face demands by those they have been sent to assist and by the international community to solve the insoluble as if it were some mathematical puzzle.

Given the increased role in crises of humanitarian agencies, in particular UNHCR, do they need additional rights and powers to fulfil the expectations placed upon them? ${ }^{5}$ Further, if they have these greater rights and this increased role, should they assume a greater degree of responsibility in international law, or should responsibility remain with

' A.D. Smith, The Eitrix Origun of States, (1986); see generally, E. Gellner, Nations and Nationatism, (1983), cop. at 53ff. Also Smith, 'Nations and their Pasts'; Gellner, 'Do Nations have Navels?'; and Smith, 'Memory and Modernity: Reflections on Emest Gellner's Theory of Nationalism', 2 Nations \& Nationalism 358-88 (1996).

${ }^{2}$ See T. Franck, 'Clan and Superclan: Loyalty, Identity and Community in Law and Practice', 90 A7LL 359, 360 (1996); N. MacCormick, 'Beyond the Sovereign State', 56 MLR 1 (1993).

3 See K. Landgren, 'Safety Zones and International Protection: A Dark Grey Area', 7 IJRL 436, 437 (1995).

4 FJ. Hampson, 'States' Military Operations Authorized by the United Nations and International Humanitarian Law', in L. Condorelli (ed.), The Unitod Nations and Hunaritarion Lavo, (1996), 371; H. McCoubrey and N. White, The Blue Helmets: Legal Regulation of United Nations Metitary Operations (1996).

${ }^{3}$ The political question of whether UNHCR should be expanding its role is not addressed in this paper except in so far as its role calls into question its obligations under its Statute; see further below, note 28. In times of general financial constraint, however, it is sensible to focus on one's core obligation which, in the case of UNHCR, is protection. See also, W. Clarance, 'Field Strategy for the Protection of Human Rights', 9 IJRL 229 (1997). 
States? This latter question is complicated, however, by the fact that States often seek to restrict their obligations to displaced persons and may be imposing extra burdens on UNHCR in order to avoid their own duties. Moreover, where a State mistreats refugees, ${ }^{6}$ UNHCR is criticized for not preventing it, rather than the State being acknowledged as responsible under the 1951 Convention relating to the Status of Refugees. UNHCR can protest, usually privately, but its only other option would be to withdraw, leaving the refugees with no independent voice. At the same time, UNHCR has also adopted a more active and self-directed role as regards certain crises. In sum, the background picture is less than clearly defined. $^{8}$

This article examines the rights, existing, required or desired, of UNHGR and the responsibilities it ought to assume in humanitarian crises: ${ }^{9}$ those responsibilities may be legal or they may merely reflect issues of good governance. The hope is to provide a framework for the better analysis of the international law relating to the work of agencies, particularly UNHCR, which protect displaced persons during humanitarian crises.

\section{The End of Bipolarism}

Although the strictly bipolar view of the world was already somewhat simplistic by the end of the 1980s, any analysis of present-day conflicts as aspects of a wider superpower confrontation would be unsubstantiated in fact. ${ }^{10}$ For refugees, the end of bipolarism has led to a decrease in their strategic and political value to States who had previously been eager to use their 'persecution' as justification for the confrontation. " As a result of the end of bipolarism, the United Nations has had an increased role in humanitarian crises in terms of peacekeeping and peace-making, and

${ }^{6}$ See Kenya's actions, reported in the Guortian, 31 Jul. 1997, 9.

7189 UNTS 50. And see the 1967 Protocol, 606 UNTS 267.

${ }^{a}$ See N. Morris, 'Protection Dilemmas and UNHCR's Response: A Personal View from Within UNHCR', 9 IJRL 492, 492, 496-7 (1997).

9 It may be possible to transfer the principles of this analysis to other IGOs and some NGOs; however, while they face similar problems to UNHCR, they present a very different framework of analysis. The other major actor in humanitarian crises, the International Committee of the Red Cross, may possess international legal personality through its activities, but is in fact a private Swiss non-governmental organization; see J-P. Lavoyer, 'Refugees and Internally Displaced Persons: International Humanitarian Law and the Role of the ICRC', 305 IRRC 162, 167 (1995).

${ }^{10}$ For a view of the strategic nature of refugee movements, see G. Loescher, Refugee Movenents and Intemational Secrrity, Adelphi Paper No.268, 1992, 28ff; and A. Roberts, Humanikarian Action in War, Adelphi Paper No.305, 1996, 12-14.

"See UNHCR, UNFCR Strakgy Towards 2000 (1996), at para.18. See also, G.W. Hymans, 'Outlawing the Use of Refugees as Tools of Foreign Policy', 3 ILSA 7. Int'l \& Comp.L 149 (1996). 
has had to take on more onerous responsibilities toward those caught up in the conflict. ${ }^{12}$

In the 1990s the Security Council has not merely found itself able to do things which it could not previously do. It has found itself expected to do something about conflicts of a type outside the United Nations' previous experience. While the United Nations cannot do everything, the United Nations is particularly well-placed to take action in the name of the international community. It is not inappropriate in principle for the United Nations to be involved in enforcement action and peace-enforcement operations. ${ }^{13}$

A clear example is the establishment of a safe haven in Northern Iraq for the Kurdish population in the aftermath of the Gulf War in $1991 .^{14}$ At the time of their establishment, before Iraq's agreement to the presence of United Nations Guards, ${ }^{13}$ it is arguable that Northern Iraq was occupied territory, an occupation justified under, the UN Charter. Other intergovernmental organizations (IGOs) have equally adopted a more interventionist stance. While the Dayton Agreement affirms UNHCR's lead role in the humanitarian relief in Bosnia-Herzegovina, both the Organization for Security and Co-operation in Europe and the European Union have administrative functions which incline towards them fulfilling tasks within Bosnian society normally associated with sovereign governments. The European Union, for example, which is not even explicitly stated to have international legal personality in the Treaty of Maastricht, is responsible for the City of Mostar in Bosnia-Herzegovina, evidencing through practice what is not express in the treaty. ${ }^{16}$

If there is increased interventionism within States, how far are IGOs, and in particular the United Nations, responsible in international and domestic law for their actions and those of persons working for them?

${ }^{12}$ Sce Locscher, Refugee Moxements, 52-3; Raberts, Humanitarian Acton, 10-18. See also, A. Roberts, 'The Laws of War. Problems of Implementation in Contemporary Conflicts', in European Commission, Law in Humanitarian Crises, vol. I, 13-82 (1995).

13 Hampson, 'States' Military Operations', 425.

14 H. Cook, The Safe Haven in Northen Iraq, 1995.

is Sec UNSC res. 688 (1991), 30 ILM 858 (1991), in which the Security Council '3. Insists that Iraq allow immediate access by international humanitarian organizations to all those in need of assistance in all parts of Iraq and to make available all necessary facilities for their operation ...' and '5. Requests further the Secretary-General to use all the resources at his disposal, including those of the relevant United Nations agencies, to address urgently the critical needs of the refugees and displaced Iraqi population.' The United Nations Guard was agreed to by Iraq in a Memorandum of Understanding of May 25 1991: UN doc. S/22663, 30 ILM 860 (1991). See Cook, The Saje Hazen an Northen Iraq, 56ff. UNHCR's presence in Northern Iraq was covered by a Memorandum of Understanding of 18 Apr. 1991 between Iraq and the Secretary-General's Executive Delegate and a request by Iraq on April 23 that the United Nations should take over the Centres being established by the Allies' Combined Task Force Provide Comfort (I am grateful to Nicholas Morris of UNHCR for this information).

16 Cf. Reparations Case, below, note 17. D. McGoldrick, Intemational Relations Lan of the European Union, 1997. The Dublin proposals of 5 Dec. 1996 recommend in Ch. 13 that the European Union be accorded international legal personality, see also, European Rqport, No.2210, 26 Mar. 1997, $2 f f$. 
The United Nations is not a State, so the law pertaining to State responsibility is not immediately applicable. Nevertheless, the United Nations, at least, has international legal personality. In the Reparations Case, ${ }^{17}$ the International Court of Justice (ICJ), acknowledging the role the United Nations was intended to fulfil according to its founders, with its attendant duties and responsibilities, held that the attribution of international personality in large measure was indispensable. Whilst the United Nations was not a State, 'it is a subject of international law and capable of possessing international rights and duties ...' That it could be liable in domestic law was recognized by the 1946 Convention on the Privileges and Immunities of the United Nations. ${ }^{18}$ These privileges and immunities, though, can be waived. ${ }^{19}$ In addition, there is a question as to how far the United Nations, and other IGOs, can be responsible in international law. Like States, responsibility should only be civil, not criminal. ${ }^{20}$ However, a contrast has to be drawn between the position of IGOs in humanitarian crises and any troops sent as peacekeepers or peacemakers. The latter remain national contingents, bound by the law of armed conflict in so far as it applies, ${ }^{21}$ with the sending State responsible for any violation. ${ }^{22}$ Workers for IGOs, on the other hand, do not incur the liability of their country of nationality for acts committed on behalf of the IGO. To that extent, there is greater need to look at the responsibility of IGOs.

17 Reparation for Injurwes Suffered in the Senuce of the Unuled Natons Case, Advisory Opinion, [1949] ICJ Rep. 178-9.

Is UKTS 10 (1950), Cmd 6753; see N.S. Rodley, 'Immunities of Officials Associated with Permanent United Nations Establishments', 26 ro. World Aff. 314 (1972).

${ }_{19}$ Standard Chartered Bant o Intemational Ton Councal [1986] 3 All ER 257.

20 See the International Law Commission's Draft Code on State Responsibility, art 19 of which describes some breaches of international law by States in terms of international crimes. Part I of the Draft Code can be found in [1980] $76 . I L C$, vol II (Pt 2), 30-4. For a critical view of the criminalization of State Responsibility see, LC. Green, 'New Trends in International Criminal Law', 11 Israeli Tb.H.R. 9, 24-40 (198I); K. Marek, 'Criminalizing State Responsibility', 14 R.B.D.I. 460 (1978-79) and G. Gibert, 'The Criminal Responsibility of States', 39 ICLQ 345 (1990); R. Rosenstock, 'Current Developments: The Forty-Seventh Session of the International Law Commission', 90 A7IL 106 (1996), and V. Morris and M-C. Bourloyannis-Vrailas, 'Current Developments: The Work of the Sixth Committec at the Fiftieth Session of the UN General Assembly', 90 A7LL 491 (1996).

${ }^{21}$ See Hampson, 'States' Military Operations', and McCoubrey and White, Blue Hebmes.

22 See Canada's experience of violations committed by its troops in Somalia (Guatian, 5 Apr. 1993, 8; 17 Jan. 1997, 15; 3 Jul. 1997, 21) and in Bosnia-Herzegovina (Guantian, 18 Jan. 1997, 12); also in the case of Somalia, with regard to Belgian forces (Guartion, 12 Apr. 1997, 21; 23 Jun. 1997, 14; 1 Jul. 1997, 12) and Italian forces (Guartian, 7 Jun. 1997, 18; 25 June 1997, 15; 28 May 1998, 7: international edition). Somali faction leaders have claimed that they should receive damages from the UN for the behaviour of these troops: Guation, 12 Jul. 1997, 14; Alex de Waal, 'A Brutal Peace', Editorial, Guantian, 30 Oct. 1997, 21. 


\section{The United Nations High Commissioner for Refugees $^{23}$}

People working for UNHCR are, for the most part, accorded functional immunity. The Office of the High Commissioner is an integral part of the United Nations and thus within the 1946 Convention on Privileges and Immunities. ${ }^{24}$ In articles VII and following of the UNHCR's Model Co-operation Agreement with Governments (Model Agreement), UNHCR, its officials and experts on mission are to benefit from the relevant provisions of the 1946 Convention and 'such additional privileges and immunities as may be necessary for the effective exercise of the international protection and humanitarian assistance functions of UNHCR. ${ }^{25}$

Thus, the starting point must be that ordinarily UNHCR and its staff will not be liable in domestic law for any wrongdoing associated with carrying out their jobs, although article XV allows the Secretary-General of the United Nations to waive that immunity with respect to personnel where it would otherwise impede the course of justice and it can be waived without prejudice to the interests of the United Nations and UNHCR. ${ }^{26}$ The privileges and immunities of UNHCR itself cannot be waived under the Model Agreement, ${ }^{27}$ although article XVI deals with the settlement of disputes between UNHCR and the host government. That, however, summarizes the traditional, solely domestic position, whereas it is the contention of this paper that given the increased role for UNHCR during the 1990s, it is necessary to reconsider the rights required and the responsibilities to be assumed by UNHCR in a wider context.

23 UNHCR has been chosen because of the leading role placed upon it by States and the United Nations in humanitarian crises.

24 Above, note 18.

25 Additionally, Article X states that the UNHCR Representative and Deputy Representative and other senior officials shall be treated in the same manner as diplomatic envoys and enjoy full diplomatic immunity; see 1961 Vienna Convention on Diplomatic Relations 1961: 500 UNTS 95.

26 The fact that immunity stems from the 1946 Convention on the Privileges and Immunities of the United Nations and waiver should not prejudice the interests of the United Nations as well as UNHCR that leads to this function being given to the Secretary-General rather than the High Commissioner. This does not mean that UNHCR has no separate personality from that of the Secretariat of the United Nations; see Article XVI - where UNHCR and the host government have a dispute and cannot agree on an arbitrator, they seek the services of the President of the ICJ to resolve the problem, not the Secretary-General.

27 Although UNHCR could waive it in practice; see Standard Charlared Bank o ITC, above, note 19, at 262-3. 


\subsection{The Role of UNHCR}

The role of UNHCR is laid down in its Statute, 'providing international protection to refugees', ${ }^{28}$ and in the Convention and Protocol relating to the Status of Refugees. ${ }^{29}$ Nevertheless, the role has developed to fit the times and has been added to by the General Assembly and the Economic and Social Council (ECOSOC). UNHCR is also advised by the Executive Committee of the UNHCR Programme. ${ }^{30}$

UNHCR's primary purpose is to protect the safety and welfare of people who have been uprooted or threatened by persecution, armed conflict and human rights violations. In its efforts to fulfil that objective, the organization seeks lasting solutions to the plight of refugees and other displaced people, primarily by means of voluntary repatriation and reintegration, and strives to mitigate the problems confronting those countries and communities affected by forced population displacements. By supporting national and international initiatives to ameliorate conditions in countries of origin, thereby enhancing the security of people who might feel compelled to seek safety elsewhere, UNHCR is increasingly engaged in the effort to avert refugee movements and other forced displacements ... Since the late $1980 \mathrm{~s} . \ldots$ a growing proportion of UNHCR's activities has taken place within countries of origin, both in zones of active conflict, and in the context of multidimensional peacekeeping, peacebuilding and conflict resolution operations. ${ }^{31}$

From being responsible only for protection under the Statute and for ensuring that member States honour their obligation under article 33 not to refoule persons falling within the strict definition found in article 1 of the 1951 Convention, UNHCR's role has expanded incrementally and exponentially to cover victims of war and human rights violations, as well as persons who have not managed to cross an international frontier and even to assisting in stabilization in potential source States. ${ }^{32}$ The High Commissioner herself has recognized this ${ }^{33}$ and has noted the problems to which it gives rise.

28 UNGA res.428(V) Annex, UNGAOR Supp. (No.20) 46, UN doc.A/1775, 14 Dec. 1950, Statute of the Office of the United Nations High Commissioner for Refugees; see in particular paras. $1-3,9$ and 11. The General Assembly has since adopted further resolutions defining the High Commissioner's role; see HCR/LNF/48/Rev.2.

${ }_{20}$ Above, note 7. The UNHCR has the duty of 'supervising the application of the provisions' by States of the Convention and Protocol: art. 35 CSR51, art. II (I) CSR P67.

${ }^{30}$ Currently there are fifty-three States on the UNHCR Executive Committee (EXCOM), including the five permanent members of the Security Council. EXCOM Condusions might reflect customary international law, but on their own, like General Assembly resolutions, they have no binding force in international law and are solely recommendatory. Moreover, whereas one can use General Assembly resolutions as evidence of custom, in part because nearly all States are members of the United Nations, almost three-quarters of UN Member States are not on EXCOM; EXCOM Conclusions are akin to General Assembly Resolutions, only weaker.

31 'UNHCR 2000', above, note 11 , at paras.1 and 5.

${ }^{52}$ See also, 'UNHCR 2000 ', above, note 11 , paras. $32,33$.

3s See the speech of Sadako Ogata, 'World Order, Internal Conflict and Refugees', John F. Kennedy School of Government, Harvard University, 28 Oct. 1996, 1-2. 
[n-State activities raise] ... difficult questions as [they touch] upon national sovereignty. Consent of the State concerned is an essential condition for UNHCR to exercise its protection function toward internally displaced persons. In many instances, however, there is no functioning government to grant consent as the country may de facto be governed by competing military and political factions. ${ }^{34}$

UNHCR is to be non-political and is to act in the humanitarian interest, ${ }^{35}$ yet this neutrality is challenged when the more interventionist stance of the United Nations leads to it being perceived as favouring one side or the other. ${ }^{36}$

\subsubsection{The Scope of UNHCR\} Mandate}

UNHCR is a subsidiary organ established by the General Assembly under article 22 of the United Nations Charter. ${ }^{37}$ The scope of its mandate is to be found in its Statute. ${ }^{38}$ However, the Statute refers to the High Commissioner following policy directives from the General Assembly and ECOSOC and that the General Assembly may determine that the High Commissioner shall engage in additional activities, subject to resource limitations. ${ }^{39}$ UNHCR also considers the advice of the Executive Committee. ${ }^{40}$ There is, however, no reference to the role of the Security Council and the Statute only refers to the Secretary-General in Chapter III Organization and Finances, where paragraph 17 provides that 'The High Commissioner and the Secretary-General shall make appropriate arrangements for liaison and consultation on matters of mutual interest.'

The constitutional position of UNHCR within the United Nations system reflects its role. Under paragraph 2 of its Statute, the High Commissioner's work is to be non-political, humanitarian and social. To avoid the politicization associated with the United Nations Secretariat, ${ }^{41}$ the High Commissioner is to be nominated by the Secretary-General, but is elected by the General Assembly. ${ }^{42}$ The High Commissioner should follow the policy directives of the General Assembly and ECOSOC and reports annually to the General Assembly. ${ }^{43}$ Thus, taking directions from the Secretary-General to the exclusion of the General Assembly might amount to a partial breach of mandate. ${ }^{14}$ Nevertheless, despite the attempt

34 Above, note 33, 2.

35 UNHCR Statute, above, note 28 , para. 2.

${ }^{36}$ See Landgren, 'Safety Zones', 457-8; and Roberts, 'Humanitarian Action', esp. 29-35, 51-6 and $82-4$.

37 See UNGA res. 319 A (IV), 3 Dec. 1949.

3 Above, note 28 .

99 Statute, above, note 28 , paras. 3,9 .

40 In 1996, the Executive Committee delegated some of its authority to a Standing Committee.

4 See G.S. Goodwin-Gill, The Refuge in Intemational Law, 2nd ed. 1996, 214f, csp. note 43.

42 Statute, above, note 28 , para. 13.

43 Above, note 28, paras. 3 and 11 , respectively.

4 The Secretary-General has been able to invile the High Commissioner to participate in United Nations humanitarian efforts since 1972 (UNGA res. 2956 (XXVII), para. 2, (12 Dec. 1972). I am grateful to Jean-Nicolas Beuze, LIM student 1996-97, for discussions on this point. 
to separate and distance the work of the High Commissioner from the political decisions of the Secretary-General, one recent event suggests that the Secretary-General does not always fully accord the High Commissioner her intended independent standing: Boutros Boutros-Ghali ordered UNHCR to resume humanitarian assistance in the former Yugoslavia after Sadako Ogata had withdrawn it in protest. ${ }^{45}$ This event suggests that the High Commissioner may not be solely answerable to the General Assembly, despite the Statute. ${ }^{46}$ As for the Security Council, it could give directions to a State which would also require the High Commissioner to act so as to assist in the maintenance or restoration of international peace and security. ${ }^{47}$ However, in that case, any violation of mandate in response to a Chapter VII resolution would presumably be unchallengeable following the ICJ's decision in the Lockerbie case. ${ }^{48}$

Whereas the Statute gives the General Assembly power to extend the range of the High Commissioner's activities, that power, since it is within the Statute, must be exercised so as not to violate the Statutory mandate. Of course, there is nothing to stop the General Assembly from drafting a new Statute, and the present confusion comes from incremental additions to UNHCR's role and the question whether they represent a new general mandate or whether they are ad hoc. Even more so than the General Assembly, the Secretary-General, to the extent that any instruction to the High Commissioner to act is constitutional, must also instruct in conformity with the Statute and accepted General Assembly extensions. The Security Council, on the other hand, could, in theory under a Chapter VII direction to members of the United Nations, ${ }^{49}$ indirectly

15 Guartian, 18 Feb. 1993, 8; 19 Feb. 1993, 10; 20 Feb. 1993, I; 22 Feb. 1993, 8.

16 The proper response is evidenced by the practice of the present incumbent. Kofi Annan, in consultation with the High Commissioner, condemned the then rebel forces in the 1997 Zairean civil war for denying UNHCR and other relief organizations access to refugees from Rwanda who were meant to be considered for repatriation, achieving access for UNHCR once more: Guartian, 26 Apr. 1997, 14; 29 Apr. 1997, 8; 15 May 1997, 17.

${ }^{47}$ UNHCR has been given functions by the Security Council in response to humanitarian crises in many resolutions in recent years; sce, for example, UNSC res.787 (1992), 16 Nov. 1992, in which para. 19 called on the Secretary-General and High Commissioner to promote 'safe areas for humanitarian purposes'; to that extent, it is recognized that displacement can be a threat to international peace and security. So far, every extension of UNHCR's role by the Security Council, and for that matter the Secretary-General, has been with prior consent of the High Commissioner (again, I am indebted to Nicholas Morris for his comments on an earlier draft). That still leaves open whether a Chapter VII Resolution is binding on non-State actors under arts. 41 and 42 of the Charter, but the ICJ's decision in the Lockerbe case, (below, note 48), indicates the subservience to the Security Council of United Nations institutions, at least.

${ }^{48}$ Case Conconung Questions of Interpredation and Application of the 1971 Montroal Convention Arising from the Acrial Incidant at Locketric, Libyan Arab Jamahivira o Unived Kingdom and the USA, [1992] ICJ Rep., 3, paras. 39ff: 31 ILM 662 (1992); F. Beveridge, 'The Lockerbie Affair', 41 ICLQ 907, 916-19 (1992). Cf. J-E. Alvarez, 'Judging the Security Council', 90 A7IL 1 (1996). A resolution under Chapter VI would not necessarily be unchallengeable.

${ }^{49}$ UNSC res.941 (1994), 23 Sept. 1994, para. 5, called on the Bosnian Serbs, who are not a member State of the United Nations, to give unimpeded access to UNHCR to Banja Luka, Bijeljina and other areas of concern. 
require UNHCR not only to act beyond its mandate, but contrary to it if that was necessary to restore international peace and security. ${ }^{50}$

Parallel to its mandate, one must also have regard to UNHCR's legal personality in international law, its functional capacity. ${ }^{51}$ Given that UNHCR is a subsidiary organ of the General Assembly, it has only that degree of personality conferred by the latter organ of the United Nations. Under paragraph 8 of the Statute, ${ }^{52}$ it is assumed that UNHCR will have independent legal personality on the international plane, for,

[the] High Commissioner shall provide for the protection of refugees falling under the competence of his Office by:

(a) Promoting the conclusion and ratification of international conventions for the protection of refugees, supervising their application and proposing amendments thereto. (emphasis added)

In article 35 of the 1951 Convention, ${ }^{53}$ States have agreed that they will facilitate UNHCR's supervision of the application of the Convention's provisions. In both instances, UNHCR is treated as being able to function vis-à-vis States in a general supervisory capacity with regard to refugees. Following the Reparations Case, ${ }^{54}$ the particular international rights and duties of UNHCR, 'depend upon its purposes and functions as specified or implied in its constituent documents and developed in practice.'

In theory, UNHCR cannot act beyond its statutory remit, although that provides for the General Assembly determining additional activities 'within the limits of the resources placed at [the High Commissioner's] disposal'. However, Shearer has noted that the ICJ went on to establish a doctrine of inherent powers, ${ }^{55}$ those functions 'conferred upon [the international institution] by necessary implication as being essential to the performance of its duties' ${ }^{36}$ One example is UNHCR's management of camps, not referred to in the Statute, but essential to its work of providing protection to groups of refugees. ${ }^{57}$

To whom then, does the mandate extend? ${ }^{58}$ The Statute refers solely to refugees. They are defined in paragraphs 6 and 7. While paragraph

\footnotetext{
50 What if the Security Council decided that refugee camps in State A were a threat to intemational peace and security because of their destabilizing influence and ordered State B, the source State, to readmit its population forthwith, requiring UNHCR to assist in the transfer, even though no status determination had taken place of persons in the camp and there was no guarantee that any repatriation would be voluntary?

${ }^{31}$ Personality, here, is confined to issues of functionality and no attempt is made to examine the issue in the abstract in international law.

32 Above, note 28.

3s Above, note 7 .

54 Above, note 17, at 180 .

5s I.A. Shearer, Starket Intemational Law, 1 lth ed., 1994, 548.

56 Reparations Case, above, note 17 , at 182.

37 The Statute, above, note 28, paras. 1 and 2.

so See also G.S. Goodwin-Gill, 'Who to Protect, How, ... and the Future', Editorial, 9 IJRL 1 (1997)
} 
6.A mirrors the original, restrictive definition of the 1951 Convention before it was expanded by the 1967 Protocol, ${ }^{59}$ especially with respect to the temporal limitation, paragraph 6.B is not restricted, either temporally or geographically. Thus, even if in ratifying the 1951 Convention the State limited the refugees whom it would not refoule to those whose wellfounded fear was as a result of 'events occurring in Europe before 1 January $1951,{ }^{60}$ such a State could not deny that UNHCR has responsibility under its Statute to provide international protection to refugees resulting from events outside those parameters. ${ }^{61}$ The protection may be illusory, however, for the State can refuse these refugees entry ${ }^{62}$ or deport them, subject only to custom ${ }^{63}$ and any alternative human rights obligations that might be pertinent, ${ }^{64}$ for its reservation means it does not recognize their status. Furthermore, the resolutions of the General Assembly are not legally binding unless they encapsulate customary international law, to the development of which they can also contribute. It is possible to imagine that a State could consistently object to paragraph 6.B during the debates on the High Commissioner's mandate so as to evidence its non-acceptance of this wider customary definition of a refugee to whom UNHCR owes international protection.

Finally, whereas the 1951 definition, found also in paragraph 6 of the Statute, has been interpreted highly individualistically, the Statute provides in paragraph 2 that the work of UNHCR 'shall relate, as a rule, to groups and categories of refugees'. When deciding on non-refoulement, it is natural that individual decisions are necessary, but during a humanitarian crisis international protection will be offered to the group.

This leads to another part of UNHCR's work, namely, in refugee camps. As part of receiving influxes of persons fleeing from persecution across an international border, UNHCR has, almost since its inception, provided protection in refugee camps in receiving States. The increase in numbers in those camps, however, has left UNHCR, not necessarily

59 Above, note 7. The Statute does not include 'membership of a particular social group' among the grounds for persecution, that head having been added to the 1951 Convention only at the final stages of the drafting process. Nevertheless, para. 2 of the Statute does state that the work of the High Commissioner 'shall relate, as a rule, to groups and categories of refugees'.

At 30 June 1998, only Congo, Madagascar, Monaco, Hungary, Malta and Turkey limit refugees to those arising as a result of events in Europe. Madagascar and Monaco have not yet adhered to the 1967 Protocol, so the temporal limitation is also extant in their case.

61 The Statute is renewed for five year periods. Thus, the General Assembly reaffirm their commitments in paragraph 6.B. The mandate of the Office of the High Commissioner was renewed for a further five years from 1 Jan. 1994: UNGA res.47/104, 16 Dec. 1992. The Third Committee adopted by acclamation in Nov. 1997 a resolution sponsored by 132 delegations to extend UNHCR to 2003; it was adopted by the General Assembly in Dec. 1997.

62 See the actions of Turkey following the Gulf War of 1991 vis-d-nis Iraqi Kurds: Cook, The Sage Haven in Northem Iraq, 36.

${ }^{63}$ See Goodwin-Gill, The Refugee in Intemational Lowo, 167-71.

64 See, for example, Chahal o United Kingdom, below, note 156 . 
willingly or happily, with responsibility to co-ordinate a worldwide miniempire with a population numbered in the millions. ${ }^{65}$ The Model Agreement talks of UNHCR consulting and co-operating with the host State, indicating that UNHCR is providing protection while the State remains responsible, de jure, for the people in those camps; in practice, UNHCR might co-ordinate assistance, but the day-to-day running of the camp will be in the hands of local authorities and/or NGOs distributing the relief. On the other hand, in effect, the land on which the camps lie has almost been 'leased' from the State which is no longer in de facto control of that area; international law, which maintains that the State is responsible for what happens on its territory, ignores the effective power of IGOs, which are the only bodies capable of providing for the large scale influxes of displaced persons during some humanitarian crises.

This leaves some questions unresolved. Unless the Security Council has ordained the existence of the camps under Chapter VII, then the differing obligations of the State under the 1951 Convention and UNHCR under its Statute are once again apparent: the State is under no duty to allow the establishment of the camp, other than that it might be the sole means of housing persons who have crossed the border before their refugee status can be determined; ${ }^{66}$ UNHCR, on the other hand, has the wider obligation of providing international protection and the camp may be the best means, temporarily, of achieving that end. Nevertheless, UNHCR would need the consent of the host State, although how voluntary that consent might be is open to question; when one million Rwandans crossed into the former Zaire fleeing the RPF as it took power, Kinshasa could have lawfully refused to permit the establishment of the camps along its border, however politically and economically its choice was constrained. The intricate relationship of the host State and UNHCR as regards the establishment and running of camps is a matter requiring further review.

UNHCR may not have intended to expand in the direction of camps, but these are now seen as critical to its protection mission.

Food, shelter, health care and other forms of assistance are essential to the survival and safety of displaced populations, and constitute a vital form of human rights protection in their own right, especially in situations where civilian populations are subject to deliberate deprivation - including starvation - by the parties to the conflict. ${ }^{67}$

Protection, UNHCR's primary responsibility, has necessitated the simultaneous provision of assistance and relief. Moreover, UNHCR also recognizes that this type of work attracts funding from donor governments,

${ }^{65}$ See EXCOM Conclusion 22 (XXXII) 1981, §ुII.

${ }^{66}$ See above note.

67 'UNHCR 2000', above, note 11, para. 49. 
unlike, for instance, legal protection in Western Europe. To that extent, the extension of the 'empire' is actively pursued.

It is now evident that the resources available to multilateral organizations will come under growing pressure in the immediate future. Donors also seem likely to channel their contributions selectively, favouring programmes and operations which they consider to be of the greatest strategic importance. As recent experience has amply demonstrated, relatively large amounts of money may be available for activities which benefit war-affected populations, while refugee programmes of the more traditional type fail to attract sufficient resources. ${ }^{68}$

Another increasing aspect of UNHCR's work with refugees is repatriation. While voluntary repatriation is mentioned as one of its functions in the Statute, ${ }^{69}$ UNHCR has appeared to treat it as its primary response to refugee influxes in recent years. ${ }^{70}$ It is laid down as a task of UNHCR in article I.5 of the Dayton Agreement and in the Quadripartite Agreement. ${ }^{71}$

Until a few years ago, it was assumed that repatriation could take place only after a significant change in the political order of the refugee creating country, or following a peace settlement. Today, voluntary repatriation is considered the most desirable solution to humanitarian crises, and active steps are being taken to create favourable security, political, human rights and socio-economic conditions to enable refugees and displaced persons to return home. Voluntary repatriation is now taking place to relatively safe and secure areas in countries engulfed in internal conflict or in the absence of a peace agreement. ${ }^{72}$

Whether Rwanda was safe at the end of 1996 when there were mass returns from camps in Burundi, the former Zaire and Tanzania is open to question, and Amnesty International has accused UNHCR of ignoring the human rights situation in Rwanda at that time. ${ }^{73}$ It is, without doubt, one of the main areas where the rights and responsibilities of UNHCR need reconsideration.

68 'UNHCR 2000', above, note 11, para. 68.

69 Above, note 28, paras. 1, 8(c) and 9. See also EXCOM Conclusions 18 (XXXI) 1980, 40 (XXXVI) 1985, and 74 (XLV) 1994; Note on International Protection (submitted by the High Commissioner), paras. 35-8, 9 Sept. 1991. M. Zicck, UNHCR and Vbtuniary Repatriation of Refugets: $A$ Legal Anabysis, 1997.

70 A slightly different outcome occurred in Fritrea where the government appeared not to want the refugees to return and expelled UNHCR workers for preparing an information pack on repatriation: Guartion, 7 May 1997, 11

71 Below, note 97. See also, T. Bucheli, 'The Returnees to the Gali Area: A Discussion Paper', UNOMIG 1996, 13-14, 22, and J. Walter, 'Peacekeeping by the CIS and the United Nations in Abkhazia/Georgia and Tajikistan', [1996] Int'l Peaceteeping 78

72 Ogata, 'World Order', 2-3. UNHCR has assisted the voluntary repatriation of 900,000 Somalis to relatively safe areas in Somalia which, it is recognized, is still unstable.

${ }^{73}$ See Amnesty International, 'Rwanda. Human rights overlooked in mass repatriation', 17, AI Index AFR 47/02/97, 14 Jan. 1997; 'Great Lakes Region. Still in need of Protection: Repatriation, Refoulement and the Safety of Refugees and the Internally Displaced', 5, AI Index AFR 02/07/ 97, 24 Jan. 1997. Cf. Morris, 'Protection Dilemmas', 494-5. Within UNHCR, the return from the former Zaire is now termed an evacuation. 
One of the greatest challenges facing UNHCR at present, and one which is likely to grow in the years ahead, concerns the organization's involvement in situations where refugees are returning to their own country because of external pressures or an absence of realistic alternatives. ${ }^{74}$

UNHCR is left balancing the competing interests of the host State, the source State and the refugees.

Internally displaced persons are, by definition, not refugees because they have not crossed an international frontier. Thus, UNHCR has no express statutory mandate to be concerned with them. However, being within their own State, they are of concern to international law as part of human rights law and, given that displacement will often arise as a result of armed conflict, of the international law of armed conflict, which will view them like any other group of civilians. ${ }^{75}$ To a limited extent, UNHCR's work with internally displaced persons has been recognized by the General Assembly since $1972 .^{76}$ The UNHCR Executive Committee has also sanctioned work with internally displaced persons in certain circumstances. ${ }^{77}$ The High Commissioner became involved in Bosnia-Herzegovina in 1991 upon the request of the Secretary-General, ${ }^{78}$ dealing with, at that time, internally displaced persons outside the traditional mandate; this extension at the direction of the SecretaryGeneral was continued in the Dayton Agreement. ${ }^{79}$ Furthermore, work with internally displaced persons could also be seen as a necessary part of the functions of UNHCR's mandate to work with refugees. ${ }^{80}$ Thus, where UNHCR is assisting in the repatriation of refugees, a function under the Statute, it may well be that as a matter of necessity it has similarly to provide assistance to internally displaced persons. ${ }^{81}$ In 1996, UNHCR produced its own reference manual for staff regarding international legal standards, based on the Deng report to the Commission

74 'UNHCR 2000', above, note 11, at para. 25. See also, Volume 9:4 of the Intemational Joumal of Refugee Law (October 1997), which focuses on the question of repatriation.

${ }^{73}$ L.T. Lee, 'Protection of Intemally Displaced Persons in Internal Conflicts', 3 ILSA J. Int'l E Comp.L 529 (1997).

76 UNGA res.2958 (XXVII), 1972.

$"$ EXCOM Conclusion 75 (XLV) 1994. See also, UNHCR, 'Protection aspects of UNHCR activities on behalf of internally displaced persons': UN doc. EC/SCP/87, Aug. 94. On the effect in international law of EXCOM decisions, see above, note 30.

${ }^{78}$ See E.D. Mooney, 'Presence, ergo Protection? UNPROFOR, UNHCR and the ICRC in Croatia and Bosnia-Herzegovina', 7 IJRL 407, 419-20 (1995).

79 1-21 Nov. 1995, Annex 7 Article III. 1. See also the Quadripartite Agreement $\pi$ Ablhazia, below, note 97 . Initially, the High Commissioner was to have had a similar role in relation to the Great Lakes region; the Secretary-General eventually appointed a Special Envoy to work with all affected governments and involved agencies, including UNHCR: see UN SC res. 1078 (1996), paras. 10, 13. At one time, the special envoy was the Assistant High Commissioner.

bo See the Reparations Case, above, note 17, at 182 .

81 See UNHCR, UNHCR' Oporational Experience of Worting with Intemally Displaced Persons, 1994, 3-10, 37-55. On the compatibility of assisting internally displaced persons and fulfilling its mandate to refugees, see R. Cohen, 'Refugees and Human Rights', Refugee Policy Group, Feb. 1995, 13-14. 
on Human Rights. ${ }^{82}$ Internal displacement often has the same causes as international refugee movements, ${ }^{89}$ and there is no doubt that persons forced to flee their home have need for humanitarian assistance. The International Committee of the Red Cross (ICRC), for instance, consistent with its mandate, focuses on the context in which the victims are suffering rather than distinguishing between them on the basis of the victim's reaction, to flee or stay. UNHCR, however, is not a general humanitarian organization, yet to view working with internally displaced persons as 'an exceptional occurrence' while refugees who cross an international border remain its central concern ${ }^{84}$ is to ignore reality, whether this should be UNHCR's role is simply a redundant question. The question is how this role should be regularized. The Representative of the Secretary-General on Internally Displaced Persons presented a new set of Guiding Principles on Internal Displacement to the Commission on Human Rights in 1998, proposing a definition or description which requires only that the internally displaced person or group of persons have been forced to flee, 'in particular as a result of or in order to avoid the effects of armed conflict, situations of generalized violence, violations of human rights or natural or humanmade disasters ... ${ }^{85}$ Whether there will be a United Nations High Commissioner for Displaced Persons in the future, responsible for the protection of all those displaced regardless of whether they have crossed an international border, remains to be seen.

Associated with internally displaced persons, and in some ways similar to camps, UNHCR has had to deal with 'safe areas'. ${ }^{86}$ UNHCR has welcomed the link between human rights violations, refugee flows and threats to international peace and security, ${ }^{87}$ which developed from UN Security Council resolution 688 (1991) on the Kurdish safe haven in Northern Iraq, but still has its concerns about the operation of safe

${ }^{82}$ F. Deng, Representative of the Secretary-General on Internally Displaced Persons, 'Compilation and Analysis of Legal Norms', UN doc. E/CN.4/1996/52/Add.2.

${ }_{83}$ See G. Gibert, 'Root Causes and International Law: Refugee Flows in the 1990s', 11 NQHR 413 (1993).

o4 'UNHCR 2000', above, note 11 , para.16. See also para. 40, recognizing that increasingty internally displaced persons cannot readily be separated from refugees; either they will be mixed up with returning populations or alleviating their plight might prevent a transborder influx into a neighbouring State. See also, High Commissioner's Memo No.33/93, 28 Apr. 1993, UNHCR's Role with Internally Displaced Persons, in UNHCR' Operational Exparince wiith Intemally Displaced Persons, above, note 81, Annex 1 .

os See 'Guiding Principles On Internal Displacement', reproduced with comment and introduction by Simon Bagshaw and Walter Kalin, below at 547-72.

\$ See Landgren, 'Safety Zones'; J-P. Lavoyer, 'International Humanitarian Law after Bosnia', 3 ILSA J. Int'l \& Comp.L 583 (1997), and Ogata, 'World Order', 2.

I7 'UNHCR 2000 ', above, note 11 , para. 36. 
areas. ${ }^{88}$ Given that most conflicts today are non-international and fragmented, there is less respect for the laws of war, coupled with an inability readily to distinguish those fighting from civilians. As such, protection of all civilians within the safe area, the internally displaced and those ordinarily resident there, both groups outside UNHCR's normal mandate, is difficult to achieve; ${ }^{89}$ safe areas may even have the effect of placing those outside that area in even greater jeopardy. ${ }^{90}$

Related to internally displaced persons, but sufficiently distinct so as to raise new issues concerning the scope of its mandate, UNHCR has also sought to provide in-country protection. The question arises as to what extent internally displaced persons should have rights beyond those of persons equally affected by an acute crisis, but who have not fled their homes.

The question then arises as to a possible decelopment of the law. This is a delicate matter, for there are already many legal regulations, and, when new rules are created (e.g. a convention on displaced persons), care must be taken not to undermine the existing law. Another moot point is the advisability of ereating rules aimed solely at protecting displaced persons, which could result in discrimination against other victims who also deserve to be protected."

When operating in-country, UNHCR is working with people who are not even internally displaced, although internally displaced persons may be part of a mixed community. The logic behind this extension of its activities is that if UNHCR can 'ameliorate refugee-producing conditions', then it is protecting potential refugees. ${ }^{92}$ Additionally, where the Statute lays down that UNHCR will seek permanent solutions, including repatriation, ${ }^{93}$ this is to be 'by assisting Governments'; since repatriation must be voluntary, the government to be assisted must be that of the source State, again providing support for in-country activities. UNHCR can only be successful in ameliorating refugee-producing conditions and in securing conditions conducive to voluntary repatriation by improving circumstances for the entire population.

The importance of this issue, however, lies in how far UNHCR's

88 See 'UNHCR 2000', above, note 11, para. 36, and Landgren, 'Safety Zones', 457-8. In practice the safe area may well become a prison; the operation by the Turkish government to seal its eastern border in the build-up to the possible use of armed force against Iraq by the United States and the United Kingdom by sending troops into northern Iraq to create a buffer zone, was justified by Ankara as a humanitarian aid pactage for potential refugees: Guantian, $10 \mathrm{Feb}$. 1998, 11.

${ }^{99}$ See Mooney, 'Presence, ergo protection?', 415-16, concerning the six safe-havens in BosniaHerzegovina.

90 Lavoyer, 'Refugees and IDPs', 176.

91 The ICRC has always provided assistance to all those caught up in a conflict: Lavoyer, 'Refugees and IDPs', 174-5; quotation at 179.

92 'UNHCR 2000', above, note 11, para. 42. See the High Commissioner's speech to the UN Third Committec, Nov. 1992: 4 IJRL 541 (1992); also, Goodwin-Gill, The Refugee in Intemational Law, 282ff.

93 Above, note 69 . 
extension of its in-country work should develop from providing simple humanitarian relief to more general in-State support, such as restoration of civil society. ${ }^{94}$ Examples of in-country work can be seen in UNHCR's role in Bosnia-Herzegovina, ${ }^{95}$ where it was reaffirmed as lead agency for humanitarian relief under the Dayton Agreement, ${ }^{96}$ in Abkhazia/Georgia under the Quadripartite Agreement of $1994,{ }^{97}$ and in its leading role in co-ordinating regional strategies, such as that in the CIS ${ }^{98}$ However, UNHCR is not a general humanitarian organization, and there are dangers in providing in-country protection. ${ }^{99}$ Thus, merely by increasing its in-State role delivering humanitarian relief, UNHCR's activities may result in people being unable to obtain refugee status in other countries and it may no longer be perceived as acting entirely non-politically. ${ }^{100}$ Furthermore, if UNHCR's personality in international law is to be established by its attendant duties and obligations, ${ }^{101}$ this extension of its duties and obligations must accord it greater rights and responsibilities, as well, at least on an ad hoc basis.

Finally, before looking at the rights and responsibilities of UNHCR, one needs to consider the consequences of changing the primary focus from the protection of refugees, to providing humanitarian relief to all displaced persons. ${ }^{102}$ It would, even in that case, be difficult to ignore protection, at least in so far as it accompanies the provision of humanitarian relief. ${ }^{103}$ The difference is that humanitarian relief can be provided anywhere, increasing the pressure to return refugees to their own country. Where war or human rights violations were still occurring in the source State, protection might still be provided in other parts of that State, even in 'safe areas'. Protection would become relative, to be balanced against the ability to supply adequate resources in-country. This is not to say,

94 'UNHCR's Role in National Legal and Judicial Capacity-Building', UN doc. EG/46/SC/ CRP.31 (1996). See also, UNHCR/CDR 'Reintegration in the Transition from War to Peace, Sept. 1997.

${ }^{93}$ UNHCR was initially asked to act in the former Yugoslavia by a letter from the then United Nations Secretary-General Javier Pérez de Cuéllar on 25 Oct. 1991; lead agency status is referred to in a report of Secretary-General Boutros-Ghali (S/23900), 12 Dec. 1992, para. 16 (information from various sources). See generally, Mooney, 'Presence, ergo protection?'

${ }_{96}$ Article III, Annex 7, above, note 79.

97 Between UNHCR, Russia, Georgia and Abkhazia, 4 Apr. 1994.

98 UNHCR, 'Information Note on the CIS Conference Process': UN doc.A/AC.96/855 (1995). See A.C. Helton, 'Regional Conference on Migration in the Former Soviet Union: Crucial Opportunities for the International Community', 7 IJRL 501 (1995); 'The CIS Migration Conference', 8 I $R L 169$ (1996). See also, 'UNHCR 2000', above, note 11, paras. 47, 48.

S9 See also, Cohen, 'Refugees and Human Rights', 214

100 'UNHCR 2000', above, note 11, paras. 42, 43; UNGA res.51/75, 12 Dec. 1996, para. 13: 9 IJRL 308, 310-11 (1997).

iti Reparations Case, above, note 17.

${ }^{102}$ See, for instance, a message circulated via internet ListServ from Guy S. Goodwin-Gill (3 June 1997) headed 'United Nations Reform and the Future of Refugee Protection'; the proposed reforms did not materialize.

${ }^{103}$ Cf. Mooney, 'Presence, ergo protection?', 434; 'UNHCR 2000', above, note 11, para. 50. 
however, that the mandate is not flexible; law, for the mandate should reflect the law relating to the international protection of refugees, is a tool for engineering desired results. The law simply provides parameters within which to act and legitimates authority for those actions. The mandate can and must adapt to circumstances, but the Statute and 1951 Convention cannot be ignored; expansion must not undermine the original mandate. ${ }^{104}$

It is also feared that international protection, with its basis in international law, will become peripheral to the work of UNHCR, even to the point that legal protection will give way to political expedience. ${ }^{105}$ However, UNHCR's role is changing and the original mandate needs refinement. A reconsideration, though, of UNHCR's rights and responsibilities to make them fit for the times, always bearing in mind its Statute, the 1951 Convention and earlier Executive Committee Conclusions, would provide a legal underpinning for its activities and reassert its protective function. ${ }^{106}$

\subsection{Rights, Needs and Legitimate Expectations}

Given increased interventionism in humanitarian crises, what rights does UNHCR need? Merely drawing up some new charter of rights which might subsequently be ignored by parties to a conflict would be a redundant exercise. ${ }^{107}$ However, if rights are down on paper and reflect what UNHCR truly needs to function in a humanitarian crisis, then it gives the international community a tool by which to apply pressure to

104 'UNHCR 2000', above, note 11, at paras. 17, 19-20: 'Refugee protection is the primary concern of all UNHCR activities. Indeed, it is UNHCR's mandate to safeguard the human rights of individuals who lack national protection which gives the onganization its distinctive character in relation to States, other elements of the UN system and its operational partners ... Unless the task of protection is seen in a broader context of efforts to resolve existing refugee situations and to avert new population displacements, there is a real risk that refugee protection standards will continue to decline. While many of UNHCR's efforts will be focussed on large scale population displacements, individual refugees and asylum seekers must benefit from the attention they deserve.' It might be argued that the expansion of UNHCR's activities has been ad hoc and reflected the personality and authority of the person, for example, the Secretary-General, delegating the task; thus, there has been no expansion of mandate. However, that still leaves the question of expanded activities under the delegator's authority conflicting with the original mandate; see above, note 45 and accompanying text.

${ }^{108}$ Contrary to the Statute's requirement that the work of the High Commissioner be antindy 'nonpolitical'; cf. Anonymous, 'The UNHCR Note on International Protection You Won't See', paras. 22 and 23, forwarded e-mail (18 Nov. 1996) from Refugee Studies Programme, Oxford, nọw published in 9 IJRL 265, 272 (1997).

106 In that vein, the 1997 Note on International Protection, 2 Jul. 1997, emphasizes international protection and the grant of asylum. See also, EXCOM Conchusions 81 and 82 (XLVII) 1997.

${ }_{107}$ See Yves Sandoz, ICRC, Address to Committee of Foreign Affairs and Security of the European Parliament, Brussels, 25 Jan. 1994, "The right to intervene on humanitarian grounds: limits and conditions. The right to mtervene and international law in the humanitarian field. Towards a new concept of national sovereignty', sixth conclusion. (Obtained from the ICRC website: www.icre.org) 
recalcitrant States. This section examines the needs of UNHCR if it is to carry out its extended activities, taking account of its current rights.

\subsubsection{Intervention ${ }^{108}$ to carry out the mandate}

UNHCR's Model Agreement self-evidently presupposes that it will be acting with the consent of the host government. ${ }^{109}$ The Agreement is drafted in terms intended to enable UNHCR to carry out its mandate:

Article III.4 The Government shall at all times grant UNHCR personnel unimpeded access to refugees and other persons of concern to UNHCR ...

Article XVII.2 This Agreement shall be interpreted in the light of its primary purpose, which is to enable UNHCR to carry out its international mandate for refugees fully and efficiently and to attain its humanitarian objectives in the country.

For example, the Quadripartite Agreement expressly provides that UNHCR is to have direct and unhindered access to all displaced persons and refugees from Abkhazia. ${ }^{110}$

However, is there a general right of access by UNHCR and, if so, for what purposes? Cornelio Sommaruga, President of the ICRC, has argued that there is a right to intervene to provide humanitarian assistance to a civilian population in time of international armed conflict ${ }^{111}$ and that this should not be seen as an interference with the sovereignty of the State. ${ }^{112}$ Sandoz also has recognized a right of victims to receive assistance, but noted that it was not without limitations: ${ }^{113}$

There are ... limits to this right, relating to the nature of the agency offering to bring assistance and checks on the consignments. Indeed, the obligation to allow free passage to relief consignments being sent to the civilian population of

108 Sandoz, 'The right to intervene on humanitarian grounds', and Roberts, 'Humanitarian
Action', 5 Iff. This section benefited greaty from long talks with Françoise Hampson.
109 See also McCoubrey and White, Blue Hebmets, 69f.
110 Above, note 97, Further Agreement, 4 Apr. 1994, para.(a).
111 C. Sommaruga, 'Assistance to Victims of War in International Humanitarian Law and Humanitarian Practice', 289 IRRC 373, 375-6 (1992), relying in part on art. 70, Additional Protocol I, 1977. For occupied territories within Geneva Convention IV, 1949, see arts. 23, 55 and, especially arts. 59 and 61. Sommaruga argues (376) that while consent of the Party is required, it cannot be withheld if the civilian population necds assistance and it will be provided impartially by a neutral body, such as the ICRC or UNHCR (Statute, para. 2, above, note 28). Indeed, one reading of art 70 is that the Party to the conflict is obliged to organize relief and that only the Party concerned in the relief action can object, presumably because it would not be effective or safe on the conditions laid down by the party to the conflict. Art. 18.2 Protocol II, 1977, requires the consent of the High Contracting Party (but not the rebel force) in a non-international armed conflict, but the same limits should apply; see D. Plattner, 'Assistance to the civilian population: the development of the present state of international humanitarian law', $288 J R R C 249$ (1992).

112 See also Goodwin-Gill, The Refugee in Intemational Law, 267, note 108, citing Oppenhein 5 Intemational Law. Cf. Art. 20(b), UN Personnel Convention, below, note 142. Humanitarian intervention by external armed forces is less than universally approved; see Sommaruga, 'Assistance to victims', 376-7; also, Landgren, 'Safety Zones', 443.

113 'The right to intervene on humanitarian grounds.' 
a party to a conflict, including the adverse party, may be made conditional upon checks to ensure that the contents are distributed exclusively to those for whom they are intended. Moreover, the parties to the conflict are bound to give a formal reply to any request to conduct an international relief operation, which must be humanitarian and impartial in nature, on their territory.

With regard to article 70 of Protocol I and article 18.2 of Protocol II, ${ }^{114}$ the limitations are so great that it is difficult to discern any 'right': they both need the consent of the host State which can still subject any delivery to such scrutiny that any perishable goods would not survive the journey; ${ }^{115}$ moreover, in practice, deliveries also need the consent of all the interested parties along the route. ${ }^{116}$ Sandoz argues that the limitations cannot be used to frustrate the supply of aid, for that would violate principles of the international law of armed conflict, such as not starving a civilian population to death. ${ }^{117}$ However, the international law of armed conflict does not ordinarily grant rights to individuals, but more usually, it imposes obligations on States. Human rights law, particularly the right to life set out in all human rights conventions, might found a claim to humanitarian relief for the purpose of ensuring survival, but even then that would not necessarily translate into granting UNHCR a right of access to refugees nor any other persons of concern to the High Commissioner. ${ }^{118}$

A Chapter VII resolution of the Security Council could require a State to grant access to a particular organization or organizations as part of maintaining or restoring international peace and security. ${ }^{119}$ As stated above, UNHCR has actively welcomed the link in United Nations Security Council (UNSC) resolution 688 (1991) between gross human rights violations, forced displacement and the threat to international peace and

114 Above, note 111.

115 See generally, Hampson, 'States' Military Operations', 411-15, and Plattner, 'Assistance to the civilian population', 254ff and 262. Even where relief can be supplied under art. 70, Protocol I, art 71 states that the Party in whose territory they shall carry out their duties must approve their participation and, while relief personnel are to be respected, protected and assisted, subject only to the constraints of imperative military necessity, they are to 'take account of the security requirements of the Party in whose territory they are carrying out their duties'.

116 In theory, if criminal elements or those outside the control of the State authority blocked the route, then their consent is not necessary, but in the latter case especially, they are a de facto authority who must permit the passage of relief. A favourite tactic of the Bosnian Serts was to have the old women from a village sit in the road to block it; I am indebted to Karin Landgren for this information.

117 'The right to intervene on humanitarian grounds', using art. 54, Protocol 1.

118 N. Morris, 'Humanitarian Aid and Neutrality', paras. 13 and 8 (paper presented to a symposium organized by La Fondation pour les Enudes de Dfforse, 16-17 June 1995). Published in French as part of the collection of conference proceedings in Operations des Natuans Unies - Legons de Tarrain. I am grateful to Nicholas Morris for a copy of the paper in English to which reference is made.

119 See UNSC res. 941 (1994), para. 5, above, note 49. See also, Roberts, 'Humanitarian Action', 19ff. Ch. VII may be the only solution where a State deliberately blocks aid to part of its population in a non-international armed conflict; see the allegations of the International Federation of Human Rights Leagues with regard to Belgrade's actions in Kosovo: Guantian, 9 Sept. 1998, 11. 
security. ${ }^{120}$ UNSC resolution 824 (1993), as well as unilaterally stipulating that Sarajevo, Tuzla, Zepa, Gorazde and Bihac were to be designated safe areas, required parties to the conflict to give humanitarian relief agencies unimpeded access to the safe areas. ${ }^{121}$ Furthermore, acting under Chapter VII, the Security Council could always impose relief on a recalcitrant or ineffectual State. ${ }^{122}$ Nevertheless, there is not enough supporting evidence to establish an independent right in UNHCR of access to refugees or others of concern in conflict situations.

Beyond conflict situations, it is implicit in the Statute that UNHCR will have access, but the Statute is only a General Assembly resolution. The question is, whether the implicit dimension has become a rule of customary international law. Recent evidence from Thailand ${ }^{123}$ and Kenya ${ }^{124}$ shows that UNHCR will only act in conformity with the State's domestic practice vis-à-vis refugees, which would suggest no 'right' in UNHCR, and that access remains a privilege granted by the State. ${ }^{125}$ That States generally give access is no proof that UNHCR has any right in the matter as against States.

In sum, international humanitarian law may provide a basis for developing a right of intervention to provide humanitarian relief, constrained only by the practical consequences of an armed conflict. Where there is no armed conflict, one further area for development for UNHCR would be a more generalized right of intervention to provide protection and relief to displaced persons. A right to intervene in situations other than those of armed conflict would need to be premised on an equivalent level of disruption to an armed conflict. If there is a transborder element, then the host State will usually be willing to receive outside help with respect to relief, but may not welcome the protection that such organizations provide against forced repatriation. ${ }^{126}$ If the situation only involves internally displaced persons, then, as under article 18.2 of Protocol II, ${ }^{127}$ State consent will be necessary unless matters are so bad that UN

120 'UNHCR 2000', above, note 11, at para. 36.

121 See Mooney, 'Presence, ergo protection?', 416. Access was not forthcoming. Cf. the experience of Open Relief Centres in Sri Lanka which were set up consensually: Landgren, 'Safety Zones', 452; Guartion, 4 Sept. 1998, 15 (Setbian constraints on aid centres in Kosovo).

${ }_{122}$ See the Memorandum of Understanding between Iraq and the Allies, above, note 15; indeed, it has been Turkey which has impeded access.

123 See Human Rights Watch/Asia, 'Burma/Thailand: No Safety in Burma, No Sanctuary in Thailand', HRW Short Report, vol.9:6, 18, Jul. 1997.

124 Guantian, 31 Jul. 1997, 9.

120 UNGA res.51/75, 12 Dec. 1996, para. 6 (at 309), only 'emphasizes the importance of ensuring access' by UNHCR, indicating that it is not an obligation of States.

${ }^{126} \mathrm{Cf}$. the Tanzania Crisis of late 1996, where UNHCR did little to prevent the mass expulsion of Rwandese back to Rwanda, having already agreed the date of their return with the Tanzanian government; Amnesty International, 'Great Lakes', 2, 7-9. The issue is discussed in detail below.

127 Above, note 111. 
authorized humanitarian intervention would be justified; ${ }^{128}$ it may be either that a State is engaging in gross human rights violations or that the economy has deteriorated so far or that there is some natural disaster and, as a consequence, that the population is suffering severely. ${ }^{129}$

At present, there is no right, as such, of access to provide protection, or to intervene to provide relief. At best, UNHCR may be able to claim under humanitarian law that it has a right to offer assistance, although it may not want to do so without some recognition of its right to offer protection. Where a State permits ${ }^{130}$ UNHCR to provide relief, then UNHCR will be acting lawfully, but that is not the same as saying UNHCR has a right of access to provide protection. ${ }^{131}$

\subsubsection{Protection in the Host State ${ }^{132}$}

Article VI.5 of the Model Agreement obliges the government of the host State to 'take the necessary measures, when required, to ensure the security and protection of the premises of the UNHCR office and its personnel'.

The Quadripartite Agreement provides for a joint guarantee of United Nations' and the co-operating agencies' staff and property by the Russian Federation, the Georgian side and the Abkhaz side. ${ }^{133}$ Thus, UNHCR will seek the protection of not just the host State, but also groups in control of territory where it will be operating and any independent security force. Sometimes, however, it should be able to call on the international community where host-State protection is not forthcoming

128 See N.S. Rodley, 'Collective Intervention to Protect Human Rights', in Rodley, N., ed., To Loose the Bands of Wickedness (1992). See also, R.B. Lillich, Humanitarian Interoention and the United Nations, 1973; J.N. Moore, Law and Cioil Wor in the Modem World, 1974; T. Franck \& N.S. Rodley, "After Bangladesh: The Law of Humanitarian Intervention by Military Force', 67 AJIL 275 (1973); F.R. Teson, Humanitarian Interaention (1988).

129 See UNSC res.688 (1991), above, note 15, which linked intervention by relief organizations with repression of part of a population by the State and a threat to international peace and security. See also, Landgren, 'Safety Zones', 454-5.

190 Sometimes the permission will be implied, such as where a State has collapsed and there is no central authority to give permission; see quotation in text at note 34 above. In those circumstances, the humanitarian crisis will involve internally displaced persons, not refugees, and no one would claim UNHCR has a 'right' of access to them. Moreover, States do not collapse without warning, so it is likely that UNHCR will already be operating in such a State with the permission of the previous administration; whether those who gain de facto control of an area of a collapsed State will honour such permission is doubtful (I am grateful to Nicholas Morris for sharing his views on this matter).

131 It is arguable that a Contracting State would be under a duty to co-operate with UNHCR in its protection function under art 35 CSR51. On the other hand, the State's obligations under art. 6 ICCPR66 (right to life) and art. 11 ICESCR66 (to take appropriate steps to ensure the realization of everyone's right to an adequate standard of living, including adequate food), do not add to the argument that UNHCR should have a right of access for the purpose of protection, particularty since derogations from art. 11 would be permissible during the crisis.

132 See also Convention on the Prevention and Punishment of Crimes Against Internationally Protected Persons including Diplomatic Agents, New York, 1974, 13 ILM 42 (1974).

133 Above, note 97, para.(c). 
or is inappropriate. ${ }^{134}$ In Bosnia-Herzegovina, UNHCR needed the support of UNPROFOR because the Bosnian forces could not provide protection in Serb-held areas; ${ }^{135}$ in the former Zaire, UNHCR was left with no UN protection in the camps and had to rely finally on 1,500 of former President Mobutu's elite guard. ${ }^{136}$ Given the fragmented nature of conflicts, the idea that UNHCR could derive all the security it needs from the host State is decidedly anachronistic; at times, and where possible, a joint agreement with all warring factions within a State may be adequate, but if the international community wishes UNHCR to 'solve' refugee crises, it must be willing to provide protection to unarmed humanitarian relief workers. ${ }^{137}$ The respect which UNHCR and the ICRC used automatically to receive from all parties is a thing of the past, ${ }^{138}$ and the risks for aid workers have increased. ${ }^{199}$ As with Additional Protocol I to the Geneva Conventions, ${ }^{140}$ it should be possible for non-State entities to* undertake that they will abide by an agreement on rights and responsibilities in humanitarian crises; at present, rebel groups have no incentive to respect the security of relief workers, but if their ultimate goal was to take over the State or secession, then compliance with a convention guaranteeing the security of those providing humanitarian relief might be seen as a means, no

${ }^{154}$ See Sadako Ogata, 'Peace, Security and Humanitarian Action', Alastair Buchan Memorial Lecture, IISS, London, 3 Apr. 1997.

133 According to Mooney, 'Presence, ergo protection?', 418-19, that support was not always forthcoming, but her view that UNPROFOR did nothing while UNHCR convoys came under fire is questionable as a generalization. UNPROFOR would return fire if it was possible to locate the source and that was within range. Moreover, UNPROFOR did not have access to all parts of Bosnia-Herzegovina; some towns were reached through the Krajina in Croatia. Finally, in some instances in central Bosnia-Herzegovina, it was the Bosnian government forces that attacked the convoys in an attempt to provoke military intervention.

${ }_{136}$ Amnesty International, 'Great Lakes', 4. See also, Ogata, 'Peace, Security and Humanitarian Action'.

137 See Roberts, 'Humanitarian Action', 51ff. See also Guardian, 22 Sept. 1998, 7 (statement to General Asecmbly by the British Prime Minister on UK's willingness to enter agreement with UN on provision of troops to support UN's role as 'guardian of global peace and sccurity'). It needs to be clearly stated that if there is the political will to use force to ensure the delivery of relief, then it would be better directed to reaching a settlement of the cause of the displacement. However, there are short-term and long-term objectives and during the process of dealing with the cause of the displacement it will remain necessary to meet the immediate needs of the affected population, in terms of protection and assistance. See also Guartian, 6 Aug. 1998, 18 (statement by Executive Director of WFP on famine in Sudan).

${ }_{138}$ See the Guartion, $17 \mathrm{Feb} .1997,10$; $18 \mathrm{Feb}$. 1997, 12, on the successful outcome to a hostagetaking of UN and ICRC personnel by a Tajik 'warlord'. However, an ICRC representative was murdered in Bosnia-Herzegovina on 18 May 1992, three Spanish aid workers were killed in Rwanda in Jan. 1997 by extremist Hutu militants: Guartian, 21 Jan. 1997, 12, and four ICRC workers were killed by rebels in Sierra Leone: Guartian, 17 Oct. 1998, 17.

${ }_{199}$ One option is to close a camp where workers are at risk; see Landgren, 'Safety Zones', 452 on Sri Lankan Open Relief Centres.

${ }_{140}$ Above, note 111, art. 96.3. 
matter how remote, of proving to the international community that they are responsible and organized. ${ }^{141}$

For the time being, the Convention on the Safety of United Nations and Associated Personnel ${ }^{142}$ may be of limited assistance. Articles 7 to 9 provide that a host State is to protect UN and associated personnel in any UN operation to maintain or restore international peace and security, or where the Security Council or the General Assembly has declared... that there exists an exceptional risk to the safety of the personnel participating in the operation'. ${ }^{143}$ Such personnel shall not be taken hostage and, if they are, then they shall be promptly released, and States are to make criminal certain offences committed against them. While the Convention is well-intentioned, it may not be effective in achieving its ends, simply because intervention in humanitarian crises tends to be of a mixed military and humanitarian nature. The actions of the military arm of the intervention may well put in jeopardy the safety and security of humanitarian workers on the ground. Furthermore, there is nothing to bind rebel forces in the Convention ${ }^{144}$ and the threat of criminal prosecution for hostage taking or article 9 crimes has a limited deterrent quality against persons waging a war against their government. ${ }^{145}$ This Convention would have had more chance of achieving its goal if it had taken an inclusive approach to the parties to the conflict. Protection of humanitarian workers in the increasingly fragmented conflicts requires the participation of all parties to a conflict, but will likely only be accepted by States if it does not enhance the claim of any rebel group.

\subsubsection{The support of Western States}

UNHCR depends on financial support, perhaps has a legitimate expectation in that regard, but hardly has a right to it. It is extremely difficult to maintain neutrality if financial support for the organization's work is not guaranteed, however, and UNHCR should not need to have

141 Some might argue that such an agreement would result in peacekeepers being put at greater risk. However, peacekeepers are normally armed to protect themselves, have rules of engagement and, generally, are put at risk because they have been deployed where there is no peace to keep; where conflict still rages, or even quietly smoulders, peacekeepers are at risk, while their presence may effectively threaten the independent, non-partisan status of relief workers. Ogata, 'Peace, Security and Humanitarian Action, 6-7.

142 UN doc. A/RES/49/59, 9 Dec. 1994 (hereinafter, the UN Personnel Convention); 34 ILM 482 (1995). See also, Summary Report of the ICRC/GIIS Seminar on the Security of Humanitarian Personnel in the Ficld for NGOs, 5 Dec. 1997; M-C. Bourloyannis-Vrailas, 'Safety and Security of United Nations Personnel in Areas of Internal Armed Conflict', 48 RHDI 95, 104ff (1995).

${ }^{143}$ Art. $1(\mathrm{c})$.

14 Cf. Art. 96(3), Protocol I, above, note 111. There is a duty to disseminate information about the Convention: art. 19.

145 Indeed, given the threat of being pursued for art. 9 crimes throughout the word, because of States' obligations under arts. 13-15 to extradite or prosecute, there may be a temptation to murder hostages in order to leave no witnesses. See also, Hampson, 'States' Military Operations', at note 29 and accompanying text 
to rely on eye-catching international humanitarian crises to encourage donor States to meet the known and ongoing costs of the organization. ${ }^{146}$

The financial commitment is part of a wider obligation to share in the overall cost of displacement. ${ }^{147}$ Burden sharing can be achieved not just by taking in refugees, but, where appropriate, through sending troops to assist in the stabilization process or by financial contributions to current costs during a humanitarian crisis ${ }^{148}$ and to the rebuilding of the economy.

Donors and international financial institutions must be drawn more systematically into the peace-building process. For it is unreasonable to expect the world's wartorn States to manage the triple transition from conflict to peace, from dictatorship to participatory governance, and from centralized or shattered economic systems to market economies, without experiencing new forms of social conflict, political instability, persecution and displacement. ${ }^{199}$

On the other hand, Western States ought not to close their borders to refugees. ${ }^{150}$ Refugee problems are not solved by ensuring that displaced persons are 'protected' in camps inside the source State or just across the border. ${ }^{151}$ It does not follow that because Western States are contributing, militarily or financially, to a humanitarian crisis at source, that they thereby fulfil all their obligations to refugees from the area. ${ }^{152}$ Under article 35 of the 1951 Convention, States parties are to co-operate with UNHCR in the exercise of its functions, but as that Office has pointed out,

[Governments] do not always respect this responsibility and in recent years have manifested a growing tendency to challenge the basic tenets of refugee protection. In these difficult circumstances, UNHCR relies to a great extent on its moral authority ... to ensure that States and other actors act in accordance with international refugee law and humanitarian principles. ${ }^{153}$

146 See UNGA res.51/75, 12 Dec. 1996, para. 20, (311-12); Guantran, 9 Sept. 1998, 11 (UNHCR appeals for 33 million to 'avert tragedy' in Kosovo); see also, A. Acharya and D.B. Dewitt, 'Fiscal Burden Sharing', in J.C. Hathaway, ed., Reconceving Intemational Refugee Law, 1997, $111 \mathrm{fr}$.

${ }^{147}$ Sec J.C. Hathaway and R.A. Neve, "Toward the Reformulation of International Refugee Law: A Model for Collectivized and Solution-Oriented Protection', paper prepared as part of York University's Center for Refugee Studies' Research Project, 'Toward the Reformulation of International Refugee Law', Sept 1996, 58-60.

${ }^{148}$ See Hampson, 'States' Military Operations', 382; Hathaway and Neve, 'Toward the Reformulation', 54ff.

149 'UNHCR 2000', above, note 11, at para. 60. See also, Ogata, 'World Order', 2.

${ }^{150}$ With the tragic consequences seen in the Adriatic Sea when an Italian warship interdicted a vessel carrying persons flecing the collapse of Albania: Guantar, 31 Mar. 1997, 10; Goodwin-Gill, The Refuge in Intemational Law, 161-7. See also the Turkish action on its Eastern frontier in the buildup to threatened conflict between Iraq and the United States and United Kingdom: Guartian, 10 Feb. 1998, 11 .

131 Cf. Germany's desire that Kosovar Albanians do not come to Germany but remain in the Cursed Mountains of high Albania: Guartion, 17 Jun. 1998, 11 ; 16 Sept 1998, 3.

${ }^{152}$ See the Statute, above, note 28, at para. 8(d). Cr. Hathaway and Neve, 'Toward the Reformulation', 54.

153 'UNHCR 2000', above, note 11, at para. 62; Guantion, 20 Mar. 1997, 14. 
One of the damning indictments of some Western States' attitude to people fleeing the conflict in Bosnia-Herzegovina, as Mooney points out, ${ }^{154}$ was their reluctance to take refugees because, in their eyes, the presence of UNPROFOR, UNHCR and the ICRC meant that there was adequate protection from persecution at home. ${ }^{155}$ Not only did this ignore the reality of the situation in Bosnia-Herzegovina, it also failed to meet international obligations to permit individuals to seek asylum and not to return them to inhuman and degrading treatment or torture. ${ }^{156}$ Fear of permanent settlement in the State giving refuge may have led to this minimalist approach to rights for displaced persons, ${ }^{157}$ but the work of UNHCR in-State should not limit other States' obligations to all persons seeking protection under the 1951 Convention and customary international law. ${ }^{158}$

Finally, UNHCR should be able to expect Western States to do all in their power, even where this is very little, to prevent refugee flows. ${ }^{159}$ Many displacements result from armed conflict or gross human rights violations, and the Geneva Conventions and Additional Protocol I require all High Contracting Parties to ensure respect for the laws expressed therein; secondly, there is a similar obligation in the European and American Conventions on Human Rights, ${ }^{160}$ while the United Nations Charter requires member States to pledge themselves to take joint and separate action to achieve universal respect for and observance of human rights. ${ }^{161}$

UNHCR may have to play a more active role in the political arena, encouraging States and non-State actors to acknowledge their responsibility for the causes and consequences of forced population movements and the protection of displaced people. ${ }^{162}$

194 'Presence, ergo protection?', 408-9.

135 See also, Landgren, 'Safety Zones', 438.

136 Chahal o Unted Kutgdom (70/1995/576/662), 15 Nov. 1996: 9 IJRL 86 (1997), concerning the refusal of refugee status to a person from India. It may be, however, that returning refugecs to a region of a State under the control of their own ethnic group, but not wholly secure, would not amount to torture, inhuman or degrading treatment. Cf. Turkey's proposal to set up, with European Union funding, reception centres from which UNHCR would be excluded (Council of the European Union, 6938/1/98, Rev.1, 21 Apr. 1998, from the Presidency to the K4 Committee); the EU rejected this plan on the basis that refugees might become the victims of rfoulement. Guartian, 29 May $1998,15$.

Project.

${ }_{132}$ Cf. J-F. Durieux, c-mail message, 15 Aug. 1996, to Centre for Refugee Studies Reformulation

159 See Goodwin-Gill, The Refuge in Intemational Law, 167ff.

${ }_{159}$ For fuller treatment, see Gilber, 'Root Causes'.

160 ETS 5 (1950) and 9 ILM 673 (1970).

161 Arts. 55 and 56.

162 'UNHCR 2000', above, note 11, at para. 15. And see V. Gowlland-Debbas, 'La responsabilite internationale de l'Etat d'origine pour des flux de refugiés', paper presented at Sacitte franfaise pour le droil infernational, 1997. 
Intervention in another State is still seen as a violation of sovereignty, even where the protection of displaced persons is concerned. Nevertheless, the greater facility within the Security Council to reach agreement allowed for the establishment of the Kurdish safe area in Northern Iraq. That was done swiftly, as a result of the particular circumstances, while the international community abdicated responsibility for the Abkhaz crisis, ${ }^{163}$ was slow to take effective action in Bosnia-Herzegovina, and arguably never did so in relation to the Great Lakes Crisis. ${ }^{164}$ Mooney even suggests that the presence of UNPROFOR, UNHCR and the ICRC in Bosnia-Herzegovina actually acted as a human shield protecting the Serb (and occasionally Croatian) forces from intervention by the West. ${ }^{165}$ In the view of the High Commissioner,

It is accepted that multilateral action has a role to play in preventing armed conflicts and negotiating peace agreements in internal conflicts. It is less clear to see how these actors - states, political and opinion leaders, NGOs and international organizations - can be mobilized on a long-term path to building peace. Can the large number of activities required for dealing with conflicts and the transition from war to peace, such as peace-keeping, electoral assistance, human rights promotion, demobilisation, refugee repatriation, humanitarian assistance and development aid be sequenced, co-ordinated and, most importantly, sustained to reach the point of preventing the recurrence of violence? The tool of indirect intervention through humanitarian action has become increasingly crucial but is not enough. ${ }^{166}$

To this, Morris adds that, 'Humanitarian action saves lives but cannot substitute for the political will necessary to reach peace ... In the absence of the necessary political will, and especially when substituting for it, humanitarian action risks being compromised or perceived as compromised .... ${ }^{167}$

\subsubsection{Problems}

Many conflicts are now fragmented, without any one party being in control in the State; sometimes, indeed, States appear to be no more than the lines on the map, with no central authority. ${ }^{168}$ There are also

163 While UNHCR and Russia were parties to the Quadripartite Agreement, above, note 97, it is alleged that the Russians used their position to further their own goals in Abkhazia: see E.D. Mooney, 'Internal Displacement and the Conflict in Abthazia', 3 J7GR 197, $218 f$ (1996).

164 See Landgren, 'Safety Zones', 447-8, and Amnesty International, 'Great Lakes', 13. The Carnegie Commission has called for a standing United Nations rapid reaction force to meet similar crises: 'Preventing Deadly Conflict', 1998.

163 Mooney, 'Presence, ergo protection?', 434. More likely, only UNPROFOR was an effective shield.

166 Ogata, 'World Order', 6.

167 See Morris, 'Humanitarian Aid and Neutrality', para. 1.

168 See Ogata, 'World Order', 2; also, 'UNHCR 2000', above, note 11, para. 38: 'In certain instances and especially when State authority is weak, has collapsed or is only gradually reasserting itself, an international presence in the form of peacekeeping forces, humanitarian organizations and human rights monitors can create a situation of shared responsibility towards civilian populations.' 
cases where States do not co-operate. In Northern Iraq, for example, Operation Provide Comfort was arguably an occupying force, rather than one engaged in providing assistance with consent; ${ }^{169}$ only when there was the Memorandum of Understanding with the United Nations did the relief effort become consensual. ${ }^{170}$

It has been suggested above that humanitarian agencies may have a right, subject to meeting certain criteria, to provide relief, but that this will place them in apparent opposition to those fighting against the population in need of assistance. In non-international armed conflicts, particularly inter-ethnic conflicts, the distinction between the civilians and those fighting may be difficult to draw. In providing relief for besieged Bosnian Muslims, for instance, UNHCR would often need the help of UNPROFOR to carry out the delivery and would appear to be acting against the Bosnian Serbs. Relief work is meant to be non-partisan, but one of the intended objectives of the conflict in the former Yugoslavia was to force people to flee, so that giving one side the resources to allow them to remain led unavoidably to UNHCR seeming to favour one party to the conflict. ${ }^{171}$

Any system of rights and responsibilities for humanitarian agencies must recognize these problems. ${ }^{172}$ Providing relief by force challenges accepted tenets of relief and puts relief workers on the ground at risk of unjustified retaliation. ${ }^{173}$

\subsection{The Responsibilities of UNHCR}

If UNHCR needs greater authority because of its more interventionist role, the necessary corollary is that it, and other agencies acting in a similar manner, must assume greater responsibilities. ${ }^{174}$ It is arguable that on the basis of the Certain Expenses of the United Nations case, ${ }^{175}$ a distinction can be drawn between actions within the spirit and intendment of UNHCR's Statute which are improperly carried out, and those which are beyond what is within its functional objectives - the latter might leave it responsible for its actions. Article 13 of the ILC Draft Code on State Responsibility provides that the conduct of an international

169 Hampson, 'States' Military Operations', 397-8, and Lavoyer, 'Refugees and IDPs', 176.

${ }^{170}$ See above, note 15.

17 See Ogata, 'Peace, Security and Humanitarian Action', 4; Morris, 'Humanitarian Aid and Neutrality', paras. 4-9. The ICRC seems to be more prepared to eschew the help of the military in order to maintain its neutral status; see C. Sommaruga, 'Humanitarian Action and Peace-Keeping Operations', 317 IRRC 178, 179 (1997).

172 See Ogata, 'World Order', 3.

ins Ogata, 'World Order', 4: 'Referring to the situation in Northern Iraq in 1991 ... UNHCR was given the task to protect, assist and reintegrate the Kurds ... in a less than fully secure environment and with 500 UN Guards monitoring their fate.'

${ }_{174}$ A concept not much in evidence in the High Commissioner's lecture at the IISS: 'Peace, Security and Humanitarian Action'. Cr. Morris, 'Humanitarian Aid and Neutrality'.

${ }^{173}$ [1962] ICJ Rep. 151; 3 ILM 545 (1964). 
organization shall not necessarily be considered the act of a State in the territory or under the jurisdiction of which it takes place. ${ }^{176}$ However, article 9 establishes, under the rubric, 'Attribution to the State of the conduct of organs placed at its disposal by another State or by an international organization', that:

The conduct of an organ which has been placed at the disposal of a State by another State or by an international organization shall be considered as an act of the former State under international law, if that organ was acting in the exercise of elements of the governmental authority of the State at whose disposal it has been placed.

Since UNHCR will be acting with the consent of the host State in most cases, then its acts will leave the host State responsible as long as it was 'acting in the exercise of elements of the governmental authority' of that State.

The two senses of responsibility, 'responsibility for' and 'responsibility to', run parallel in this analysis; however, UNHCR still remains largely unaccountable in practice.

\subsubsection{Responsibility towards individuals under UNHCR protection}

If UNHCR now operates in States where there is no functioning government, then how far should it assume responsibility for the 'safety and well-being of civilian populations'? ${ }^{177}$ Under paragraph 1 of the Statute, the High Commissioner shall provide international protection to refugees within the scope of the Statute (paragraphs 6, 7 and 9), and this is to be achieved, (1) by promoting the conclusion and ratification of international conventions and supervising their application; (2) through special agreements with Governments to improve the situation of refugees; and, (3) promoting the admission of refugees to the territories of States. ${ }^{178}$

If UNHCR fails to fulfil its mandate, should it be responsible in international law to those individuals within its protection for mandate breaches which give rise to a violation of human rights standards? And, if so, what, if any, should be the consequences? Inter-governmental organizations (IGOs) do not generally ratify international human rights treaties, and nothing in general international law imposes duties under international human rights treaties on non-State actors; at most, UN agencies are bound to uphold those parts of international human rights and humanitarian law which are customary and where custom lays down

\footnotetext{
176 Above, note 20.

177 'UNHCR 2000', above, note 11, at para. 38. See also, W. Clarance, 'Field Strategy', 230: '[There] is the need of the post-Cold War environment, with an increasing number of sensitive situations relating to conflich, either before, during or after, where large groups of persons are at risk and the only politically acceptable source for the protection they require is the international community.'

${ }^{178}$ Statute, para. 8(a), (b) and (d), above, note 28; see also art 35 CSR51.
} 
that the agency should be bound. United Nations subsidiary organs may have to uphold the human rights standards established in resolutions if those resolutions are treated as internal law, but they are not obliged by reason of the Convention itself. On the other hand, article 20 of the UN Convention on the Safety of Personnel provides that, ${ }^{179}$

Nothing in this Convention shall affect: (a) The applicability of international humanitarian law and universally recognized standards of human rights as contained in international instruments in relation to the protection of United Nations operations and United Nations and associated personnel or the responsibility of such personnel to respect such law and standards. (emphasis added)

Even if article 20 reflects international law, because UNHCR and similar relief organizations operate in periods of crisis, the standards would be those applicable where a State had derogated. However, the right to life and the right to be free from torture and inhuman and degrading treatment are always non-derogable, so issues surrounding repatriation could more readily impose a high level of responsibility. ${ }^{180}$

Voluntary repatriation is within the UNHCR Statute, ${ }^{181}$ is addressed in 1969 OAU Convention Governing the Specific Aspects of Refugee Problems in Africa, ${ }^{182}$ and is the subject of Executive Committee Conclusions adopted in 1980, 1985 and $1994 .{ }^{183}$ A current question is how 'voluntary' does voluntary repatriation have to be? ${ }^{184}$ 'Voluntary repatriation' suggests that the refugee is willing to return to the country of his or her nationality. This is a subjective test, and one of UNHCR's functions has traditionally been to establish the essentially voluntary character of repatriation. ${ }^{185}$ UNHCR's 1996 handbook, Voluntary Repatriation: Intemational Prolection, states (at page 10) that '[the] principle of voluntaniness is the cornerstone of international protection with respect

179 Above, note 142.

180 The European Court of Human Rights in Cruz Varas o Sweder, Series A, vol.201 (1991), held that there had to be substantial grounds for believing there was a real risk of torture, inhuman or degrading treatment (paras. 69-70) and this rist assessment was to be based on information known at the time of the return. See abo Chahal o United Kingdom, Case No. 70/1995/576/662, 15 Nov. 1996.

181 Above, note 28, para. 1. See also, Zieck, UNHCR and Whluntary Repatriation.

182 Art V: 1001 UNTS 45.

183 Conclusion 18 (XXXI), 1980; 40 (XXXVI), 1985; and, 70 (XIV) 1994. See also, SubCommitte of the Whole on International Protection, 23rd Meeting, 'Information Note on the Development of UNHCR's Guidelines on the Protection Aspects of Voluntary Repatriation', EC/ SCP/803, 3 Aug. 1993.

184 I am grateful to Alex Neve for his assistance in this matter. See aleo, Human Rights Watch, 'Uncertain Refuge. A HRW Short Report', vol.9.1, Apr. 1997.

103 EXCOM Conclusion 18 (XXXI) 1980, paras.(b) and (c). See also, 40 (XXXVI) 1985: '(b) The repatriation of refuges should only take place at their freely expressed wish; the voluntary and individual character of repatriation of refugees and the need for it to be carried out under conditions of absolute safaty, preferably to the place of residence of the refugee in his country of origin, should always be respected.' (emphasis added) 
to the return of refugees. ${ }^{, 186}$ To that end, refugees are to be provided with opportunities to view conditions in their State of origin prior to returning. ${ }^{187}$ Furthermore, if a refugee population decides to return spontaneously of its own volition, UNHCR has a responsibility to 'provide timely and effective protection and assistance, to the extent possible, in the country of origin', ${ }^{188}$ and after return, it is part of UNHCR's mandate to monitor the situation of the former refugees. ${ }^{189}$

On the other hand, in appropriate circumstances, UNHCR should promote voluntary repatriation as the best solution to a refugee crisis. ${ }^{190}$ In a perfect world, protection would be offered until conditions were such that the refugee population all wished voluntarily to return to their country of nationality; unfortunately, as has been noted above, host States may find the presence of the refugee population is a destabilizing burden. That places competing pressures on UNHCR: to ensure that the refugees truly wish to return and yet, simultaneously, to decide when repatriation will be safe and then to promote it. Thus, it is possible that 'voluntary' will be read as 'safe', an objective test, where individuals may be told that they must return. ${ }^{191}$ Indeed, protection and voluntary repatriation require a differentiated and dual response from UNHCR. ${ }^{192}$ What should be beyond question is that voluntary repatriation should never amount to refoulement. The problem arises where conditions in the host country are such as to engender spontaneous return as the preferable alternative, even before conditions in the country of origin are suitable.

\footnotetext{
186 Cf. Takahashi, S., 'The UNHCR Handbook on Voluntary Repatriation: The Emphasis of Return over Protection', 9 IJRL 593 (1997).

187 EXCOM Conclusion 18 (XXXI) 1980, para. (c). See also, Quadripartite Agreement, above, note 97 , at para. 10 .

${ }^{188}$ UNHCR, Handboat on Vluntary Repatriation: Intomational Protection, 1996, 23, 59ft. See also, Article V.5, OAU Convention, above, note 182 .

If9 EXCOM Conclusion 40 (XXXVI) 1985, para. (I). 'UNHCR has assisted in the voluntary repatriation of some 3.9 million Afghans since return movements began in 1989 and some 900,000 Somalis since 1992. Peace-keeping operations have also contributed toward creating the conditions for voluntary retum, and as part of peace settlement, international supervisory mechanisms have been set up to monitor the human rights situation, incluting that of the returnes, inside countries, as in Bosnia and Herzegovina, Rwanda and Haiti': Ogata, 'World Order', 3 (emphasis added). One would expect that the human rights situation of the returnees would have priority since they are the objects of UNHCR's mandate, but the High Commissioner's statement at a press conference on 1 Sept. 1998 to the effect that forced labour for Rohingya refugees returning to Burma from Bangladesh was 'something like taxation, and that she could neither say that it was good or bad, nor that it was a human rights violation, does make one wonder . . . (transcript by Burma Centrum Nedertand). Cf. 'Report of the Commission of Inquiry appointed under Article 26 of the Constitution of the International Labour Organization to examine the Observance by Myanmar of the Forced Labour Convention', 1930 (No. 29), 20 Aug. 1998; available at http//www.ilo.org/

190 EXCOM Conclusion 18 (XXXI) 1980, para. (a); 40 (XXXVI) 1985, para. (c).

$191 \mathrm{Cf}$. in the African context, Article V.1 of the OAU Convention, above, note 182, provides that States parties are obliged to ensure that 'no refugee shall be repatriated against his will'. UNHCR's role is to promote, not execule voluntary repatriation.

192 A similar dual response is recognized by the ICRC in situations involving internally displaced persons; Lavoyer, 'Refugees and IDP', 174.
} 
Sometimes, however, repatriation takes place under duress. ${ }^{193}$ In those circumstances, UNHCR's role is to provide protection from refoulement and, at the same time, ensure the safest possible conditions for those having to return. ${ }^{194}$ It is in a no-win situation, but its overall responsibility to refugees implies that it should do all in its power to avoid participating in repatriation under duress; like the ICRC, it should be more willing to condemn too hasty repatriations. ${ }^{195}$ The 1996 Great Lakes Crisis raises many questions about UNHCR's dual role of protection and repatriation. ${ }^{196}$ It is generally accepted that the vast majority of Hutus who fled Rwanda in 1994 were prevented from returning by members of the previous government in the camps through intimidation and misinformation. ${ }^{197}$ UNHCR could not run the camps as it desired. In such circumstances, it is debatable whether it should have withdrawn; ${ }^{198}$ some would argue that the organization's presence ensured, for as long as possible, the survival of the refugees/hostages, but the contrary argument is that several other UN agencies can provide relief and they do not risk losing their reputation and mandate for protection. ${ }^{199}$ In a similar situation in Thailand in the 1980s, UNHCR left the running of the camps close to the Kampuchean border in the hands of the United Nations Border Relief Organization. ${ }^{200}$ Even a hostage population deserved the internationally accepted guarantees against refoulement; no less did the almost one million refugees in Tanzania who, with the consent of UNHCR, were told by the government that they had to return by the end of $1996 .{ }^{201}$ With UNHCR workers prevented from exercising any protection, the Tanzanian army forced the refugees back into Rwanda, ${ }^{202}$ even as returning Hutus were being killed there and in Burundi ${ }^{203}$ While the former Zaire was beyond the control of UNHCR, and UNHCR deserves sympathy for not receiving the proper support

193 'UNHCR 2000', above, note 11, paras. 25-31.

194 Cf. Mooney, 'Presence, ergo protection?', 411 , note 15, and accompanying text.

193 Lavoyer, 'Refugecs and IDPs', 170.

196 See the Amnesty International Reports, 'Great Lakes' and 'Rwanda'.

197 See EXCOM, Overview of Regional Developments (October to December 1995), paras. 32-40: EC/46/SC/CRP.1 1, 4 Jan. 1996; Guantian, 12 Apr. 1997, 19.

190 UNHCR closed the Atroush camp in Northem Iraq because it alleged it could not run it as it wished: Guartion, 2 Apr. 1997, 8. It seems to have learned its lesson in Albania, where people flecing Kosovo have not been put in camps, but are housed with the local population, lest the camps are abused by the Kosovo Liberation Army: Guartion, 17 Jun. 1998, 14.

199 G.S. Goodwin-Gill, 'Rwanda-Zaire: Refugee Camps and the Protection of Refugees', 8 IJRL 630, 632-3. See the report of Kofi Annan: Guantian, 17 Apr. 1998, 16.

200 Locscher, 'Refugee Movements', 52.

201 The Agreement may be found in 9 IJRL 328 (1997). See also Human Rights Watch News, 17 Dec. 1996, 'Tanzania - Government and UNHCR must respect international law', Guartian, 14 Dec. $1996,17$.

202 See also Guantion, 5 May 1997, 11; 6 May 1997, 9, on the deaths of refugees returning in inappropriate conditions to Rwanda from the former Zaire for fear of the Kabila forces.

tof Guantian, 24 Jan. 1997, 14; 13 Jan. 1997, 10, respectively. 
of the international community, ${ }^{204}$ Tanzania calls into question the moral authority and the legal responsibility of the organization. To agree a date on paper for the return of all refugees in camps without expressly agreeing proper safeguards appears to condone the appearance of refoulement, in the absence of screening procedures, it cannot be doubted that some persons deserving of protection were sent back. ${ }^{205}$ That the return was the work of the Tanzanian government does not absolve UNHCR of its responsibility to protect. ${ }^{206}$

\subsubsection{Responsibility towards host States}

UNHCR might find it easier to obtain protection within States if it were not perceived as viewing camps as a permanent solution. Under the Statute and the $195 \mathrm{I}$ Convention, ${ }^{207}$ refugee status, and therefore presumably any entitlement to UNHCR protection, ends when the circumstances giving rise to its acquisition have ceased to exist. ${ }^{208}$ Thus, in that sense, all protection of refugees is temporary, for once there is no longer any fear of persecution in the refugee-generating State, the host State may return the former refugees. In practice, UNHCR must seek to maintain a balance between protection and repatriation, ${ }^{209}$ but not to balance protection against the interests of the host State.

Another aspect of its responsibility towards States concerns UNHCR's activities within the territory. ${ }^{210} \mathrm{UNHCR}$ and its personnel have immunity from proceedings arising out of their official activities, and a UNHCR worker who drove a car negligently and caused an accident could claim

${ }^{20-4}$ See Sandoz's fourth conclusion, 'The right to intervene on humanitarian grounds': 'Once the Security Council or regional bodies have decided to take action, all requisite means should be deployed or kept in reserve to make sure that the operation succeeds, whatever the circumstances. What, for instance, are the alternatives if the operation is obstructed or if those conducting it come under attack? If those eventualities are not seriously taken into account at the outset, if those launching the operation are not absolutely determined to ensure its success and to use all necessary means to that end, the crediblity of the decision-makers and the security of those involved in implementing the operation will be seriously jeopardized.'

203 Apparently, the Tanzanians undertook that those who chose not to return would be screened, but they failed to honour this.

206 The situation can be distinguished from that in Abkhazia, where UNHCR temporarily withdrew because it appeared that the Abkhazis and the Russians were preventing repatriation contrary to the Quadripartite Agreement: Mooney, 'Internal Displacement', 211-12.

207 UNHCR Statute, para. 6A(ii)(e); art. 1C(5), CSR51. 23.

200 See also EXCOM Conclusion 69 (XIIII) 1992, and 'UNHCR 2000', above, note 11, at para.

${ }^{209}$ See ICRC's condemnations, Lavoyer, 'Refugees and IDPs', 170, note 29. Voluntary repatriation must only apply to those where the conditions giving rise to refugee status still persist, for the cessation clauses indicate that there can be no problem with returning someone who formerty had refugee status, but who is no longer a refugee because the circumstances giving rise thereto have ceased to exist.

210 If the Reparations Case established that the United Nations has international personality to bring a claim where one of its employees is injured in the course of his or her duties, the corollary is that a claim may also be made against the UN. 
immunity in appropriate circumstances. ${ }^{211}$ However, all relief agencies need to show respect to the host State and not behave as though State sovereignty no longer has any relevance. ${ }^{212}$

The impact of placing a camp, usually in a rural area taking up land that could be cultivated, does little to promote good relations with the local population. Moreover, it is uncertain how far UNHCR might be responsible with regard to the conduct of refugees in camps, or generally in the country of refuge. A more interesting question concerns UNHCR's liability for policies which leave the host State responsible for a violation of international law, for example, where it fails to prevent camps from being used as a base for attacks on the country of origin ${ }^{213}$ or if UNHCR incorrectly declares that a source State is safe for return, closes a camp and permits or facilitates the repatriation of the refugee population who suffer persecution on return. There is no obvious mechanism by which UNHCR might be held accountable, although a State might defend itself before the Human Rights Committee or other supervisory organ, and argue that any breach of its human rights obligations was due to UNHCR.

\subsubsection{Responsibility of and towards other IGOs and NGOs}

Right from the beginning, it was envisaged that UNHCR would act in co-operation with other IGOs and NGOs. The Statute provides that UNHCR shall 'facilitate the co-ordination of private organizations concerned with the welfare of refugees', and distribute funds for the assistance of refugees to those private and public bodies 'best qualified to administer such assistance'. ${ }^{2 / 4}$ The Model Agreement calls in article IY.3 for local offices to establish and maintain links with NGOs. ${ }^{215}$

\footnotetext{
211 Speeding to reach a situation where emengency protection was required would be treated differently from drunkenness, for instance.

212 Sandoz, The right to intervene on humanitarian grounds' makes a related point: 'But the governments of poor States further weakened by war may well also legitimately fear a disorderly arrival $a$ masse of humanitarian organizations which are frequently ignorant of the practical and logistic constraints inherent in the situation and have little understanding of the political, social and cultural context. Humanitarian onganizations therefore have a duty to share their experiences and to adhere to certain working principles designed to minimize the destabilizing effect that their work can have, not only on the governments involved, but also on the social fabric of the communities they are trying to help.'

213 Ordinarily, the host State would be responsible; see United Nations 1970 Declaration on Principles of International Law Concerning Friendly Relations and Co-operation among States in Accordance with the Charter of the UN, UNGA Res.2625 (XXV). See also, EXCOM Conclusion No.48 (XXXVIII), 1987, para. 4(b).

214 Statute, above, note 28 , at paras. $8(1)$ and 10.

213 See S.C. DeWolf, 'Practical Aspects of UNHCR-NGO Partnership', paper for the PARinAC Conference in Addis Ababa, March 1994. Morris, 'Protection Dilemmas', 497, suggests that one necessary development is for UNHCR to be prepared to explain its practice in any particular situation to other agencies, a nascent duty to inform on a much wider scale: ibid., 497-8.
} 
UNHCR has also improved inter-agency co-operation with other United Nations bodies, such as WFP and UNICEF. ${ }^{216}$

However, limited funds are available for relief work and the different agencies and organizations are, to a certain extent, 'fighting for the same pot $^{\prime}{ }^{217}$ Relief agencies and NGOs, therefore, need to promote their own humanitarian works in order to keep their name in the public eye, ${ }^{218}$ and this does not readily foster inter-organizational co-operation. Donor States increasingly see IGOs and NGOs as the most reliable means of ensuring that funding reaches the population, ${ }^{219}$ and are more likely to channel relief that way.

UNHCR is in regular, close co-operation with the ICRC. ${ }^{220}$ In situations of armed conflict, both UNHCR and the ICRC have responsibilities toward refugees. ICRC's role is to uphold international humanitarian law, and to protect all civilians, including refugees, but where conflict has ceased it takes on a subsidiary role. ${ }^{221}$

The final aspect of UNHCR's relationship with other IGOs and NGOs is that it ought not to try to do everything. ${ }^{222}$ To 'solve' a refugee crisis, the conditions in the source State must have sufficiently improved for repatriation to be, at minimum, safe. The social infrastructure in the State will often need to be rebuilt, ${ }^{223}$ but this is not UNHCR's job; in Europe, that task is increasingly falling to the OSCE, ${ }^{224}$ while there and elsewhere it should be for UNDP and other agencies. UNHCR has a vested interest in the restoration, for example, of the rule of law, but it

216 See 'UNHCR 2000', above, note 11, at para. 73; see generally, Hathaway and Neve, 'Towards the Reformulation', 46ff. See also, T. Wichert, 'Human Rights, Refugees and Displaced Persons: 1997 UN Commission on Human Rights', QUNO, May 1997, on co-operation with UNHCR (E/ CN.4/1997/NGO/84, 26 March 1997); and Clarance, 'Field Strategy', 246f, 249, on UNHCRHCHR co-operation in Rwanda in the wake of the genocide.

217 Guantian, 13 Feb. 1997, 14; 28 May 1998, 5 (international edition).

218 Guantion, 20 Feb. 1997, 5; Hampson, 'States' Military Operations', 402.

219 Hathaway and Neve, 'Towards the Reformulation', 47; Guantian, 24 Jan. 1997, 2.

${ }^{220}$ See Lavoyer, 'Refugecs and IDPs', 168ff, and 'UNHCR 2000', above, note 11, at para. 38: 'UNHCR will continue to recognize the special role played by the ICRC, both as an operational agency and as the guardian of international humanitarian law.' There is also close co-operation with the Red Cross and Red Crescent Movement: Lavoyer, $176 \mathrm{f}$.

221 'The arrival of UNHCR and the negotiation of a cease-fire in the Croatian conflict in January 1992, led the ICRC gradually to phase out its relief programme and transfer responsibility for distributing aid to the displaced and those housing them to UNHCR by the end of March. In Bosnia and Herzegovina, the continuing conflict and magnitude of the need for relief has called for UNHCR and the ICRC to provide assistance simultaneously, although an informal division of responsibilities based on institutional expertise and location on the ground has averted any duplication of effort': Mooney, 'Presence, ergo protection?', 423.

220 See 'UNHCR 2000', above, note 11 , paras. $33,47,59$ and 61 .

223 Sce Ogata, 'World Order', 5.

224 Quadripartite Agreement, above, note 97, para. 6; M. Gibinicea, "The South Ossetian Conflict and the OSCE Mission to Georgia', paper distributed at the UNHCR 'Protection In and Around Conflict Training Workshop', Istanbul, 14-17 Jan. 1997; and the visit by OSCE Parliamentary Assembly Vice-President Wojciech Lamentowicz to Abkhazia to report back on the situation there: 2:1 Central Asia and Trarscancasia Nansletter 3 (1997). 
is not best positioned to give effect to it, or otherwise to bestow international peace and security all round. UNHCR has perhaps the greatest field experience in carrying out operations in acute crisis of any United Nations agency, ${ }^{225}$ but any co-ordinating role must be based on additional resources and a context in which other agencies can develop their own expertise. ${ }^{226}$

\subsubsection{UNHCR 5 responsibility to withdraw from situations where there are violations of human rights}

Many conflicts today are of an inter-ethnic nature, with displacement of others being the goal. In evacuating refugees from an area where they might be in danger, UNHCR may well assist with the illegal aims of one of the warring parties. ${ }^{227}$ UNHCR and the ICRC treat evacuation as a measure of last resort, and UNHCR suspended its operation to return displaced persons in Abkhazia because, despite the Quadripartite Agreement, the ethnic cleansing continued. ${ }^{228}$ The situation is not simple, though, ${ }^{229}$ Should one leave people to their fate lest to assist in an evacuation is to collude in ethnic cleansing? ${ }^{230}$ In the final analysis, however, humanitarian aid is cheap and saves the international community from having to commit the resources to resolve a conflict; UNHCR can hardly be blamed where it is used as a 'sticking-plaster' and has to resort to unconventional methods to avoid worse disasters. ${ }^{231}$ Nevertheless, withdrawal is an option, and an essential alternative to participation, even by presence, in human rights violations.

So far, the focus has been on attributing responsibility to UNHCR as a consequence of its increased role and the powers and rights that should flow therefrom. However, most humanitarian crises are now multi-agency operations, often including military forces, in which the attribution of responsibility is necessarily complex. States are responsible generally for harm that arises from an internationally wrongful act on their territory, ${ }^{232}$ and, where UNHCR is lead agency or is running a camp, the position appears superficially similar. UNHCR, however, lacks the

225 See Clarance, 'Field Strategy', 252-4.

${ }^{226}$ See generally Sue Lautze, Bruce Jones \& Mark Duffield, 'Strategic Humanitarian Co-ordination in the Great Lakes Region, 1996-1997: An Independent Assessment', Policy, Information and Advocacy Division, Office for the Co-ordination of Humanitarian Affairs, United Nations, New York, March 1998, paras. 162-77, 174 (available on ReliefWeb: http:/wwwnotes.reliefweb.int and on OCHA-Online: http:/156.106.192.130/dha_ol/).

${ }^{227}$ See Hampson, 'States' Military Operations', 413.

220 Mooney, 'Presence, engo protection?', 328, and 'Internal Displacement', $211 \mathrm{ff}$.

229 The only alternative may well be to establish a safe area: Landgren, 'Safety Zones', 444.

200 See Hampson, 'States' Military Operations', 328-9. In Srebrenica, the local Bosnian Muslims prevented UNHCR from evacuating people because it played into the hands of the Serbs: Guartian, 8, 5 Apr. 1993.

${ }_{231}$ 'UNHCR 2000', above, note 11, para. 67. See also, Ogata, 'Peace, Security and Humanitarian Action', 5-7; Morris, 'Protection Dilemmas', 494-5.

${ }^{232}$ See arts. 9, 13, ILC Draft Code on State Responsibility, above, note 20. 
totality of State powers, so that extending the analogy of State responsibility is hardly appropriate. Moreover, UNHCR could hardly be liable for the consequences of international inaction, such as the Security Council's failure to send adequate troops to keep the peace in the safe areas in Bosnia-Herzegovina. ${ }^{233}$

\subsubsection{Responsibility towands the International Community with respect to the non- protection of war criminals}

Events in Bosnia-Herzegovina and Rwanda have given rise to another particular issue, namely, responsibility to assist the international community in punishing those guilty of the horrendous crimes that occurred in those conflicts. This may seem self-evident, since the definition of a refugee in both the 1951 Convention and the Statute excludes those who have committed a crime against peace, a war crime or a crime against humanity or any other serious, non-political crime. ${ }^{234}$ In practice, it is impossible for unarmed UNHCR staff effectively to screen out wellarmed militia in the camps, and even UNAMIR was unable to prevent intimidation. ${ }^{235}$ When refugees were eventually forcibly returned to Rwanda, many were arrested as genocide suspects, ${ }^{236}$ and while war criminals do not deserve refugee status, their human rights should not be ignored; on return, effective mechanisms to ensure non-persecution and fair trial need to be in place.

A further issue is even more complex. UNHCR staff in the camps may well have evidence concerning those accused of war crimes. Should they be obliged to testify? ${ }^{237}$ Strict. neutrality in the face of war criminals creates a dilemma for humanitarian organizations. There are, however,

${ }^{233}$ Landgren, 'Safety Zones', 445, and Mooney, 'Presence, ergo protection?', 419 on UNHCR and ICRC having to compensate for UNPROFOR's failures.

${ }^{23+}$ See art 1F, CSR51; paras. 7, 7(d), UNHCR Statute. Cf. The Quadripartite Agreement, above, note 97 , para. 3(c), which dentes war criminals, enter alia, immunity, but also states that such persons are to be warned of the consequences of their return.

${ }^{233}$ See Landgren, 'Safety Zones', 450. Kofi Annan has called for tougher administration in refugee camps so that war criminals cannot use csvilians as hostages, but he also points out that the international community failed to meet its responsibilities in the Great Lakes: Guentian, 17 Apr. $1998,16$.

236 Guardian, 3 Jan. 1997, 9; 25 Apr. 1998, 3.

237 Hampson, 'States' Military Operations', 423. Cassese P. in Dusto Tadic, atka. 'Dule', Decision on the Defence Motion for Intertoculory Appeal on Jurisdution before the Appeals Chamber of ICTY, Case No.IT94-1-AR72 (1995), at para. 93, argued, on the basis of art. 89.1 of Protocol I to the Geneva Conventions and the ICJ's decision in Nicaragua o USA, Case Conceming Mithtary and Paramilitary Activtios in and egainst Nicaragua (Merits), [1986] ICJ Rep. 14, para. 220, that the United Nations was bound to undertake to respect and ensure resped for the Geneva Conventions because art. 1 had become a general principle of humanitarian law; this would include ensuring the prosecution of serious violations of international humanitarian law. See also, F.J. Hampson, 'The ICTY and the Reluctant Witness', 47 JCLQ 50 (1998), and the debate between Monroe Leigh and Christine Chinkin: Leigh, 'The Yugoslav Tribunal: Use of Unnamed Witnesses Against the Accused', 90 AJIL 235 (1996); Chinkin, 'Due Process and Witness Anonymity', 91 AJIL 75 (1997); Leigh, 'Witness Anonymity is Inconsistent with Due Process', 91 A7IL 80 (1997). 
competing interests. On the one hand, the international community has established international tribunals for the former Yugoslavia and Rwanda in order that serious violators do not escape punishment. ${ }^{238}$ On the other hand, UNHCR needs to consider its future access to war zones to protect victims of war, as well as the safety of its staff in camps; indeed, while former staff from the camps could not be directly prevented from giving evidence, it might be that UNHCR could claim privilege for the greater good of its continued access to war zones. ${ }^{239}$ The Rules of Evidence of the Rwanda Tribunal might provide a means of satisfying both international community and UNHCR needs. ${ }^{240}$ While Rule 70 of the Rwanda Rules permits UNHCR to give confidential evidence to the prosecutor in order that further evidence for use at trial might be discovered, Rule 75 is the only means by which a court might preserve the anonymity of a witness, even from the accused. Under the Yugoslav Rules ${ }^{241}$ Rule 70 goes further

${ }^{238}$ The Statute of Yugoslav Tribunal was presented to the Security Council in 'The Report of the Secretary-General Pursuant to Paragraph 2 of Security Council Resolution 808 (1993): 32 ILM 1159 (1993). The Statute was adopted by the Security Council in Resolution 827 (1993): 32 ILM 1192 (1993) The Rules of Procedure and Evidence (hereinafter, Rules) are now at Revision 6 IT/32/Rev.6. The Rwanda Tribunal was established under UNSC res. 935 and 955 (1994), reprinted in 5 Crim.LF 695 (1994). See also the Rome Statute of the International Criminal Court: 37 LM 999 (1998).

259 I am grateful to Marie-Claude Roberge of the Legal Division of the ICRC for her assistance on this point.

${ }_{240}$ Rules of Procedure and Evidence, UN doc. ITR/3/REV.1 (1995), entered into force 29 June 1995: "Rule 69 Prolection of hactims and Winzesses... (C) Subject to Rule 75, the identity of the victim or witness shall be disclosed in sufficient time prior to the trial to allow adequate time for preparation of the defence. Rule 70 Matters not Subject to Disclosure ... (B) If the Prosecutor is in possession of information which has been provided to him on a confidential basis and which has been used solely for the purpose of generating new evidence, that initial information and its origin shall not be disclosed by the Prosecutor without the consent of the person or entity providing the initial information and shall in any event not be given in evidence without prior disclosure to the accused ... Rule 75 Measures for the Protection of Victions and Witnesses (A) A Judge or a Chamber may, proprio motu or at the request of either party, or of the victim or witness concerned, ..., order appropriate measures for the privacy and protection of victims and witnesses, provided that the measures are consistent with the rights of the accused. (B) A Chamber may hold an in canera proceeding to determine whether to order. (i) measures to prevent disclosure to the public or the media of the identity or whereabouts of a viction or a witness, or of persons related to or associated with him by such means as: (a) expunging names and identifying information from the Chamber's public records; (b) non-disclosure to the public of any records identifying the victim; (c) giving of testimony through image- or voicealtering devices or closed circuit television; and (d) assignment of a pseudonym; (ii) closed sessions, in accordance with Rule 79.'

${ }^{241}$ Above, note 238. 'Rule 70 Matters not Subject to Disclosure ... (C) If, after obtaining the consent of the person or entity providing information under this Rule, the Prosecutor elects to present as evidence any testimony, document or other material so provided, the Trial Chamber, notwithstanding Rule 98, may not order either party to produce additional evidence received from the person or entity providing the initial information, nor may the Trial Chamber for the purpose of obtaining such additional evidence itself summon that person or a representative of that entity as a witness or order their attendance. (D) If the Prosecutor calls as a witness the person providing, or a representative of the entity providing, information under this Rule, the Trial Chamber may not compel the witness to answer any question the witness declines to answer on grounds of confidentiality. (E) The right of the accused to challenge the evidence presented by the Prosecution shall remain unaffected subject only to limitations contained in Sub-rules (C) and (D). 
and restricts the right of the Trial Chamber to demand that witnesses from, for example, UNHCR give additional information over and above that to which they have agreed. Even here, though, there is no limit on the accused's right to challenge this evidence, subject to the limits on the Trial Chamber itself. The accused has a right to a fair trial and if the prosecutor is aware of evidence (as opposed to confidential information) beneficial to the accused, no matter what the source, it must be disclosed under Rule 68. Whether the Tribunal would listen to arguments about institutional privilege and the need to preserve the organization's access to war zones in the future where the accused's rights are at stake is not so clear. ${ }^{242}$

\section{Conclusion}

The relationship between States and IGOs is in a state of flux, as is the position of IGOs in international society generally. A new compact is necessary between the UN and its agencies and States as to responsibilities for humanitarian crises. ${ }^{243}$ One way forward, so that international humanitarian relief agencies and those they protect and assist know where they stand, would be to draft a convention encompassing the major human rights commitments, to be open for signature by IGOs and other relief organizations, thereby clarifying the scope of commitment beyond their own specific and original mandates. The opening clause of the preamble to the 1951 Convention recalls that 'the Charter of the United Nations and the Universal Declaration of Human Rights ... have affirmed the principle that human beings shall enjoy fundamental rights and freedoms without discrimination ...' Thus, the idea that refugees deserve the traditional human rights in addition to the rights established in the 1951 Convention is not open to dispute. It is not doubted that UNHCR in providing protection and administering relief to refugees already operates within a human rights framework, but it should be an express commitment, reflecting the more autonomous role which UNHCR now has. Given that conflict situations already attract human rights monitors and even country rapporteurs, there would be no shortage of material by which one could evaluate UNHCR's performance ${ }^{244}$ and that of States

\footnotetext{
${ }^{242}$ Rule 70 applies to evidence for the Prosecution. Furthermore, given the fact that humanitarian organizations regularly employ people on short-term contracts for the duration of crises, it may be that any privilege based on institutional needs for the future would not be available in the case of evidence they had obtained during their employment.

${ }^{243}$ See the fourth point of the High Commissioner's conclusion, 'Peace, Security and Humanitarian Action', 6-7.

${ }^{244}$ T. Mazowiecki, 'Final periodic report on the situation of human rights in the territory of the former Yugoslavia, Special Rapporteur of the Commission on Human Rights, pursuant to paragraph 42 of Commission resolution 1995/89': UN doc. E/CN.4/1996/9, 22 Aug. 1995, paras. 124-9. There is also CNN: Hampson, 'States' Military Operations', 410 and 415, note 103.
} 
in relation to their responsibilities to refugees. ${ }^{245}$ Properly established checks on practice improve performance and prevent unofficial, illprepared analyses based on hearsay and the reporting organization's own agenda. ${ }^{246}$ However, it may be much easier to impose these extra responsibilities on UNHCR than it would be to ensure that UNHCR also enjoys the necessary additional rights set out above.

245 Wichert, 'Seeking Refuge in Geneva'.

246 Morris, 'Protection Dilemmas'. Cf. Finarcial Tones, 29 Jul. 1998, 1, 7' Guartian, 30 Jul. 1998, 12; 1 Aug. 1998, 14. 